\title{
Social Globalisation and Efficiency of Microfinance Institutions Nexus: Empirical Evidence on Financial and Social Efficiency
}

\author{
Hafezali Iqbal Hussain ${ }^{1,2}$, Fakarudin Kamarudin ${ }^{3, *}$, Nazratul Aina Mohamad Anwar ${ }^{4}$, Fadzlan \\ Sufian $^{5}$, Azlan Ali', Mohd Haizam Saudi ${ }^{7}$
}

\author{
${ }^{1}$ Taylor's Business School, Taylor's University, Malaysia; Taylor's University Lakeside Campus, 1 Jalan Taylors \\ Subang Jaya 47500, Malaysia \\ ${ }^{2}$ University of Economics and Human Sciences in Warsaw, Poland \\ E-mail.hafezali.iqbalhussain@taylors.edu.my
}

${ }^{3 *}$ School of Business and Economics, Universiti Putra Malaysia

43400 UPM Serdang, Selangor, Malaysia

E-mail.fakarudin@upm.edu.my*correspondingauthor

${ }^{4}$ Faculty of Economics and Muamalat, Universiti Sains Islam Malaysia

Bandar Baru Nilai,Nilai, 71800, Negeri Sembilan, Malaysia

E-mail.nazratulaina@usim.edu.my

${ }^{5}$ Faculty of Business and Management, Universiti Teknologi MARA, Melaka

Alor Gajah Campus, Km 26 Jalan Lendu, 78000 Alor Gajah, Melaka, Malaysia

E-mail.fadzlan.sufian@gmail.com

\author{
${ }^{6}$ School of Business and Management, University College of Technology Sarawak \\ 96000 Sibu, Sarawak, Malaysia \\ E-mail.azlan.ali@ucts.edu.my \\ ${ }^{7}$ Widyatama University, Jl. Cikutra no 204 A Bandung \\ West Java, 40124 Indonesia \\ E-mail.haizam@widyatama.ac.id
}

cross'ref http://dx.doi.org/10.5755/j01.ee.33.1.29130

The main objective of this paper is to identify the impacts of social globalisation comprised of personal contacts, information flows and cultural proximity to the financial and social efficiency of Microfinance Institutions (MFIs). This study had conducted two stages of analysis, in which the first stage is Data Envelopment Analysis (DEA) approach and the second stage is multiple panel regression analysis under Generalized Least Square estimation method. The results exhibit that the overall MFIs operated in a relatively optimal scale during the period of the study. However, these MFIs were managerially inefficient in utilising their resources to achieve both social and financial efficiency. The results from panel regression analysis showed that only personal contacts exhibit a significant positive relationship with the financial efficiency of MFIs. This study could contribute new insights and implications to various parties, such as MFIs, policy makers, investors and researchers to improve the efficiency of MFIs.

Keywords: Microfinance Institutions; Social Globalisation; Personal Contacts; Information Flows; Cultural Proximity; Social Efficiency; Financial Efficiency.

\section{Introduction}

The main focus of Microfinance Institutions (MFIs) is to provide financial services to the people with low income or to very poor individuals (Silva \& Chavez, 2015). According to Silva and Chavez (2015), MFIs provide credit in the form of small loans, insurance or saving account to the poor who faces difficulty in obtaining financial services from traditional financial institutions due to lack of stable income, collateral assets or credit histories. Consequently, the poor people can utilise the credit provided by MFIs to establish their own business and generate income in order to survive (Hermes, Lensink \& Meesters, 2011).
Efficiency of MFIs can be measured through the method of how MFIs allocate and utilise their resources, such as assets and employees, in order to produce outputs measured in terms of their loan portfolio and poverty outreach (Bassem, 2008). Efficiency of MFIs can be divided into two components in order to capture the dual goals of microfinance institutions, namely financial efficiency and social efficiency (Nieto et al., 2009). Financial efficiency in MFIs is based on technical efficiency, in which MFIs are considered achieving financial efficiency if the MFIs have generated larger productivity (Sanchez 1997). On the other hand, social efficiency indicates the ability of MFIs to manage its resources such as assets and employees (Von Stauffenberg et al., 2003). Social efficiency is related to the 
welfare policy as it evaluates the efficiency of MFIs in utilising the resources in order to bring the impacts to the society, especially on the poverty issue and women involvement in economy.

Globalisation is the increased integration of global economies through trade and capital flows, which are facilitated by the opening up of closed economies and societies as well as the incremental growth in information technology (Ezike, 2009; Kuder, 2015; Skare \& Prziklas Druzeta, 2016; Yazdi \& Dariani, 2019; Baneliene \& Melnikas, 2020; Lee et al., 2020; Mushtaq et al., 2020). Social globalisation is related to the spread of ideas, information, images, and people around the world (Norris, 2000; Dreher, 2006; Melnikas, 2019; Bilan et al., 2019). There are three main components from the aspect of social globalisation, namely personal contact, information flows, and cultural proximity (Dreher, 2006). Personal contact can be defined as the communications between people around the world through daily physical interactions, telecommunications or mails. Information flows refers to the spread of information and ideas globally and between formal and informal economies through the newspapers, television and internet. Cultural proximity captures the diffusion of cultures and social norms, with the aim to reduce the cultural barriers and information asymmetry between lenders and borrowers, which can reduce the transaction costs in processing MFIs loans and administration costs in evaluating the quality of the borrowers and in follow-up monitoring.

Microfinance is a development tool rather than just a simply banking (Ledgerwood, 1998; Ezzat \& Fayed, 2020; Hussain et al., 2020a; Hussain et al., 2021; Sufian \& Kamarudin, 2014b). MFIs are different as compared to commercial banks, in which the focus of MFIs is to emphasise on the welfare of the society, which will significantly influence the development of a country. According to Kipesha (2013), some empirical studies showed that the MFIs tend to be less efficient as compared to other financial institutions, such as commercial banks. However, MFIs should also operate efficiently and generate profit in order to sustain the service of providing loans to the poor community.

Although MFIs have high growth in loan portfolio, but they are facing challenges in maintaining the financial viability and efficiency (Opperud \& Torp, 2016). In order to gain better understanding on the reasons of the challenges faced by MFIs in achieving the financial and social efficiency, this study will be conducted to further investigate on the relationship between MFIs specific determinants, macroeconomic factors and social globalisation components to the efficiency of microfinance institutes. Therefore, the relationship between the respective independent variables, namely size of MFIs, age of MFIs, profitability, ROE, economic growth, inflation rate, personal contacts, information flows and cultural proximity with the efficiency of MFIs from both financial and social aspects will be investigated and discussed in this study.

This study will be able to provide more information on the efficiency of MFIs by identifying the potential MFIs specific and macroeconomics determinants to the efficiency of MFIs. Besides, this study could contribute new findings regarding the impacts of personal contacts, information flows and cultural proximity to the efficiency of MFIs. To sum up, the results and findings of this study could provide a better understanding on MFIs specific determinants, macroeconomic factors and social globalisation components to the efficiency of MFIs, while delivering deeper insights regarding the efficiency of MFIs to various parties such as MFIs, investors, government and policy makers.

The paper is set out as follows: Section 2 provides the reviews on the related literatures. Section 3 discusses the methods and variables applied in this study. Section 4 illustrates the empirical findings and results for this research. Section 5 concludes and discusses the implications of the study to various parties.

\section{Literature Review and Hypotheses Development}

Efficiency can be defined as the ability of the firm to maximise the production of the products and services by using the minimum level of the resources (Kipesha, 2013; Grmanova \& Pukala, 2018; Hintosova et al., 2020; MarksBielska et al. 2020). Different researches had been conducted to investigate the possible variables that influence the efficiency or performance of the firms or financial institutions such as commercial banks, microfinance institutions (MFIs) and etcetera.

Alhassan (2015) and Yazdanfar (2013) supported that a positive relationship exists between firm size measured by total assets (TA) and profitability. Large firms have better access to the resources and tend to take the advantage of economies of scale to diversify its product range, which lead to increasing profitability. On the other hand, Demirgunes and Ucler (2015) reported large firms incurred higher operation costs and long term average production costs and thus failed to utilise the resources in providing financial aid to the poor community. Although larger banks have greater market power, but they expose to higher risk and thus charge higher interest rate, which will make the borrowers to focus more on riskier projects and lead to non-performing loans, default risk and inefficient bank performance (Boyd \& De Nicolo, 2005).

According to a study conducted by Kamarudin et al. (2017), the size of Islamic banks has a favourable association with bank productivity. This conclusion is consistent with the economies of scale hypothesis, according to which the Islamic bank may benefit from economies of scale and operate at a reduced cost while improving its performance. Larger banks tend to claim greater improvements than their small and medium-sized bank rivals because larger expenses are required to improve the quality of services offered to their clients.

\section{Thus, this study hypothesises:}

$H_{\text {Ia }}$ : MFI size has a significant influence on efficiency of MFIs.

$H_{l b} M F I$ size has no significant influence on efficiency of MFIs.

Bogan et al (2008) and Abayie et al (2011) discovered that there is a positive relationship between the age of MFIs and their performances from the aspects of efficiency, sustainability and profitability. Older firms are easier to obtain the resources over a period of time (Autio, 2005). 
Yazdanfar (2013) discovered that there is a negative relationship between the age and the profitability of the firm. Muda et al. (2013) had reported that bank age has a negative and statistically significant impact on the ROE, which acts as the proxy measure of Islamic banks profitability. New banks are more profitable as compared to older banks because new banks apply and adapt to the new technologies. Older firms tend to face the occurrence of obsolescence due to their inability to adapt in the changing business environment whereas senescence happens because of their rigid regulations, routines and structures of the organisation (Coad et al., 2011; Hussain et al., 2021).

\section{Thus, this study hypothesises:}

$H_{2 a}$ : Age has a significant influence on efficiency of MFIs.

$H_{2 b}$ Age has no significant influence on efficiency of MFIs

Wijesiri and Meoli (2015) concluded that there is a significant positive relationship between profitability (ROA) and total factor productivity (TFP) growth. ROA positively associates with the progress in productivity and innovation over a period of time. MFIs with higher ROA are more likely to adapt to technological changes and invest more in innovations. Therefore, it can be said that MFIs that achieve greater financial performance will have greater TFP growth. Mia and Ben Soltane (2016) also discovered that ROA has a significant positive impact on the productivity of the banks. Wijesiri et al. (2015) reported that there is a negative and significant relationship between ROA and social efficiency, in which more profitable MFIs tend to have lower social efficiency. Zeller and Meyer (2002) also supported that the profitability of the firm negatively influence the efficiency of the firm unless adequate methods are implemented to make financial sustainability, social impact and outreach consistent.

Thus, this study hypothesises:

$H_{3 a}$ : Profitability has a significant influence on efficiency of MFIs.

$H_{3 b}$ Profitability has no significant influence on efficiency of MFIs.

Abrar and Javaid (2016) concluded that there is a positive relationship between leverage measured by debt to equity ratio (DTE) and the profitability of MFIs. MFIs that finance their assets through debt will increase their profitability. They can maintain the liquidity of the firms when they manage their finances efficiently, as they are able to make repayment to their creditors and could provide loan service to more borrowers. Kyereboah-Coleman (2007) supported that highly leveraged MFIs have better performance. Mia and Ben Soltane (2016) discovered that there is a significant inverse relationship between DTE and the productivity of MFIs. MFIs that highly rely on the leverage will put themselves in a risky position and affect its long term sustainability.

\section{Thus, this study hypothesises:}

$H_{4 a}$ : leverage has a significant influence on efficiency of MFIs.

$H_{4 b}$ Leverage has no significant influence on efficiency of MFIs.

According to Muda et al. (2013), economic growth measured by gross domestic product (GDP) has a positive relationship with the profitability of the banks. The conditions of the economy can be reflected by GDP growth rate. A growing economy will lead to an increasing demand for banking services and lower risk as compared to bad economy scenario. Al-Harbi (2019) reported that economic growth will improve banks' profitability in the long term. This is due to the reason that good economic development leads to higher economic efficiency and better profitability of the bank. Thoraneenitiyan and Avkiran (2009) discovered that there is a negative relationship between the overall level of economic development, which is measured by per capita GDP and the efficiency of the bank in East Asian countries. The banks in a country with a higher per capita GDP operate in a mature environment, which lead to competitive interest rates and lower profit margins. Sufian and Habibullah (2010) also found that negative relationship exists between GDP and the efficiency of banks in Thailand.

\section{Thus, this study hypothesises:}

$H_{5 a}$ : Economic growth has a significant influence on efficiency of MFIs.

$H_{5 b}$ Economic growth has no significant influence on efficiency of MFIs.

Sufian and Habibullah (2010) concluded that there is a positive relationship between the inflation rate that measured by consumer price index (INF) and the efficiency of the banks in Thailand. This is due to the reason that the level of inflation rate is under the anticipation of Thailand banks during the period of study. Therefore, they can gain benefit from it by adjusting the interest rates accordingly and subsequently lead to higher income. Tan and Floros (2012) found that inflation is significantly and positively associated with the profitability of the banks. During the period of study, inflation is predicted which provides the banks an opportunity to adjust the interest rates accordingly, lead to the situation that the revenues increase faster than costs and thus create a positive impact on the profitability of the banks. However, Kamarudin et al. (2019) discovered that higher inflation rates will lead to lower performance in the banking industry. This could due to the failure of management in predicting the unanticipated future inflation. Management makes incorrect adjustments to the costs and lead to the situation that costs increase faster than revenue (MacGregor et al., 2020). As a consequence, the banks will cause higher operating costs and lead to a decrease in their profits. Sufian and Habibullah (2014) found that the inflation rate negatively impacts the total factor productivity of the banks in Malaysia.

\section{Thus, this study hypothesises:}

$H_{6 a}$ : Inflation rate has a significant influence on efficiency of MFIs.

$H_{6 b}$ Inflation rate has no significant influence on efficiency of MFIs.

Sufian and Habibullah (2012a) concluded that personal contacts (PERSCONT) have significant and positive influence on the efficiency of banks that operate in the Indonesian banking industry. The empirical findings clearly supported that greater social integration significantly encourages the increase in the efficiency of the banks in Indonesia. This finding tends to support the "limited form" of the global advantage hypothesis (Berger et al., 2000). Under this hypothesis, Berger et al. (2000) argued that the institutions that operate in one or a limited number of countries with specific favourable market or regulatory 
Hafezali Iqbal Hussain, Fakarudin Kamarudin, Nazratul Aina Mohamad Anwar, Fadzlan Sufian, Azlan Ali, Mohd Haizam

Saudi. Social Globalisation and Efficiency of Microfinance Institutions Nexus: Empirical Evidence on Financial and ...

conditions in their home countries can perform their operations more efficiently as compared to the domestic banks in other countries. According to Sufian and Kamarudin (2016), there is a negative relationship between personal contacts and the performance of the banks in South Africa. Foreign banks from nations with higher capital account restrictions that operate in the South Africa banking industry tend to perform better in the condition of lower personal contacts.

\section{Thus, this study hypothesises:}

$H_{7 a}$ : Personal contacts has a significant influence on efficiency of MFIs.

$H_{7 b}$ personal contacts has no significant influence on efficiency of MFIs.

Sufian, Kamarudin and Md. Nassir (2017) concluded that there is a positive relationship between information flows (INFOFLOW) and the efficiency of the banks in Malaysia. A plausible reason could be due to the fact that capital account liberalization is usually linked with the liberalization of the financial services industry, which leads to greater competition and then erode the monopolistic profits in this industry. Badenhorst-Weiss et al. (2013) supported that information flows could positively affect the productivity of an organisation. Information sharing in complex linkages is important to the functioning of the business organisations. The flow of information influences the productivity and innovation of the business organisations as the employees could take prompt action and also plan for future activities if they receive the information in speedy condition. According to Sufian and Kamarudin (2016), there is a negative relationship between information flows and the performance of the banks in South Africa. There may be an increase in skilled labor demand in both developed and developing countries due to technological advancements and financial globalisations, especially in foreign direct investments.

Thus, this study hypothesises:

$H_{8 a}$ : Information flows has a significant influence on efficiency of MFIs.

$H_{8 b}$ Information flows has no significant influence on efficiency of MFIs.

According to Sufian and Habibullah (2012a), there is a positive and significant relationship between cultural proximity (CULPROX) and the efficiency of banks operating in the Indonesian banking industry. The banks in Indonesia tend to achieve higher efficiency level in the circumstance of greater social integration. Sufian and Habibullah (2012b) found that there is a positive relationship between cultural proximity and the efficiency of the banks in China. Greater economic integration can be created through higher trade flows, cultural proximity and greater political globalisation. On the other hand, Sufian and Kamarudin (2016) discovered that there is a negative relationship between cultural proximity and the performance of banks in South Africa. The empirical findings revealed that cultural proximity of the home country could negatively affect the performance of banks operating in foreign countries. A plausible reason could be due to the moral hazard problem on the part of the foreign banks headquarters, which will result in lack of screening and monitoring on the ability of the borrowers to make repayment to the banks.

Thus, this study hypothesises:

$H_{9 a}$ : Cultural proximity has a significant influence on efficiency of MFIs.

$H_{9 b}$ Cultural proximity has no significant influence on efficiency of MFIs.

\section{Methodology}

The main objective of this study is to investigate the impact of social globalisation components that consists of personal contacts, information flows and cultural proximity to the efficiency of MFIs. Besides, this study also identifies the potential MFIs specific and macroeconomics determinants to the efficiency of MFIs. Thus, the selection of MFIs' sample, period cover and appropriate estimation method applied should be to ensure the results provided in thus study are valid, significant and free from biasness.

In this research, the secondary data from a total of 88 MFIs in Philippines and Thailand from year 2010 until 2017 had been collected to assist in investigating the impacts of various determinants on the efficiency of MFIs in both countries. The Philippines and Thailand represent as among the developing Asia countries that used the MFIs as the significant financial institutions other than banking sectors. The number of 88 MFIs have been selected as the sample of this research due to the most complete data available. The government of Philippine had begun to concern on the rural poor since 1970s. Therefore, government had developed a program namely directed credit programs (DCPs) to provide highly subsidized credit to those low-income people in rural. However, the program had limited success and unable to sustain due to creditor unable to achieve outreach, the repayment was poor and the program is very costly to the government. In 1990s, more private sector participated in delivery of credit due to reformation of government policies. National Credit Council (NCC) specialized in provide strategy for MFIs and reinforce government marketoriented credit policy had launched in 1997 and since then, MFIs developed faster and more efficient in Philippine. In 2013, MFIs had fully mainstreamed the Philippine's banking sectors and became one of the main financial institutions in Philippine. The reason driving MFIs industry in Philippine growing due to increases of providers, products, delivery channels and outreach all over the country (Bangko Sentral NG Pilipinas, 2013). The MFIs in Philippines developing and become one of the important players in financial sectors.

Meanwhile, the MFIs in Thailand mainly categorized into three categories which are formal and large MFIs, semiformal MFIs and informal MFIs. Formal and large MFIs operates under prudential regulations; semi-formal MFIs included agricultural, savings and credit union cooperatives, registered savings-for-production groups, and the Thailand Village and Urban Revolving Fund (TVURF); and informal independent MFIs, which are established with support from external organisations, such as NGOs and local government agencies. Although the MFIs in Thailand had three main categories, however, government still dominated the MFIs activities in Thailand. Most of the private provider unable to 
compete with semi-formal MFIs which is TVURF in terms of cost. Until year 2013, due to strict regulations and licensing requirements in Thailand's MFIs sector, only one private microfinance lender was listed in Thailand (Oxford Business Group, 2019). However, the bank of Thailand and the Finance Ministry found that it is important and is necessary for MFIs growth to reduce that loan shark activities result on suffering of poor people as loan shark could charge interest rate based on their preference. Therefore, they are drafting the laws and regulation on extend MFIs loans by attracting more players and granting more licensing for both financial and non-financial institutions. One of the alternatives that considered to attract MFIs player is increase the interest rate for to $28 \%$ per year. The development of MFIs is highly concerned by policymakers as it is one of the effective to against nonformal loans problem especially loan sharks in Thailand.

There are three data sources for MFIs special determinants, macroeconomic factors and social globalisation components. Firstly, the financial data from Microfinance Information Exchange (MIX) market or www.mixmarket.org is collected to aid in examining the impacts of MFIs special determinants on the efficiency of MFIs. MIX market is a non-profit organisation that provides the market data and information regarding the microfinance services industry. Next, in order to investigate the impacts of macroeconomics factors on the efficiency of MFIs, the data is attained from the International Monetary Fund (IMF).

Lastly, the KOF Globalisation Index is applied as a measurement for the social globalisation aspect in this study. For the globalisation index, these were obtained from the KOF Index of Globalisation developed by Dreher et al., (2008). KOF indices are frequently used to measure globalisation given that the main benefit of using these indices, is that they can address the various dimensions of globalisation (Dreher \& Gaston, 2008; Balli et al., 2018). That is to say, KOF indices can be employed to illustrate multifaced phenomena such as globalisation. The KOF Globalisation Index is applied as a measurement for the political, economic and social aspects of globalisation. It was introduced by Axel Dreher at the Konjunkturforschungsstelle of ETH Zurich, in Switzerland. Globalisation has been incurred since 1970s and boosted up after the end of the Cold War. The current KOF Globalisation Index covers the period from year 1970 to 2017 . In this research, our main focus is social globalisation aspect for Thailand and Philippines from year 2010 to 2017. The social globalisation measures comprise of three aspects of data, namely personal contacts, information flows and cultural proximity.

\section{Data Envelopment Analysis (DEA)}

This approach has been applied to numerous studies that examine efficiency (Bartova \& Fandel, 2020; Kamarudin et al., 2013; Kamarudin et al., 2014; Hussain et al., 2020a; Hussain et al., 2020b; Sufian \& Kamarudin, 2014a; and Sufian \& Kamarudin, 2014b). The non-parametric DEA approach was applied in the first stage of the analysis process to investigate the efficiency of MFIs under the variable returns to scale (VRS) model, which was proposed by Banker et al. (1984). Charnes, Cooper and Rhodes (1978) further extended BCC model and formed CCR model, which is also known as constant returns to scale (CRS) model. The CCR model measures the overall efficiency (OE) or technical efficiency (TE), but it stated that there is no significant relationship between the scale of operations and the efficiency level. The assumptions of CRS model are only justifiable when all the DMUs are operating at an optimal scale, which is impractical as MFIs or DMUs may encounter either economies or diseconomies of scale in the business operation. Hence, when there are DMUs that are not operating at the optimal scale, the computation and measurement of DMUs' TE will be contaminated with scale inefficiency (SIE) by applying these assumptions.

The CCR model is further extended by Banker et al. (1984) to evaluate the pure technical efficiency (PTE) of the MFIs and decompose TE into PTE and scale efficiency (ScE). BCC model aims to increase the level of output at a given constant level of inputs. The efficiency level of DMU's management can be evaluated by TE. PTE shows the efficiency of the MFI's pure managerial without contamination by scale, whereas ScE indicates the size of the MFI. Scale inefficiency (SIE) exists when there is a difference between the TE and PTE scores of an MFI (Coelli, 1996; Sufian, 2004). The range of the TE score is between zero and one, in which the higher score indicates that DMU achieves greater technical efficiency and operates at the efficiency frontier, and vice versa.

\section{The Constant Returns to Scale Model under the CCR Model}

There are two types of DEA, which are input-oriented DEA and output-oriented DEA. Input-oriented DEA approach defines the frontier by searching the maximum possible proportional reduction in the input usage, with a constant level of output production. On the other hand, output-orientated DEA approach looks for the maximum proportional increase in the output production, with a constant level of input usage. DMUs assumed $(k=1, ., K)$, in which $x=\left(x_{1}, ., x_{N}\right) \in \mathfrak{R}^{N+}$ is denoted as the vector of input and $y=\left(y_{1}, \ldots, y_{M}\right) \in \mathfrak{R}^{M+}$ is denoted as the vector of output. Equation (1) can be applied to measure the TE of the DMU, which is shown below:

$$
\mathrm{TE}_{\mathrm{k}}=\frac{\lambda_{1} y_{1 k}+\lambda_{2} y_{2 k}+\ldots,+\lambda_{M} y_{M k}=\sum_{m=1}^{M} \lambda_{m} y_{m k}}{v_{1} x_{1 k}+v_{2} x_{2 k}+, \ldots,+v_{N} x_{M k}=\sum_{n=1}^{N} v_{n} x_{n k}}
$$

where, $\mathrm{TE}_{\mathrm{k}}=$ the technical efficiency score given to the $k$ th DMU

$\lambda=$ output weights
$v=$ input weights

Equation (2) is formed by translating Equation (1) into a linear programming, which is shown below:

$$
\begin{aligned}
& \operatorname{DEA}^{\mathrm{L}}(x, y)=\operatorname{Min} \phi_{k}^{C R S} \mid\left[\phi_{k}^{C R S} \geq 0\right] \\
& \text { s.t. } \sum_{k=1}^{K} \lambda_{k} y_{k}^{m}-s_{m}^{+}=y_{o}^{m}, \mathrm{~m}=1, \ldots, \mathrm{M} \\
& \sum_{k=1}^{K} v_{k} x_{k}^{n}+s_{n}^{-}=x_{o}^{n}, \mathrm{n}=1, \ldots, \mathrm{N} \\
& \quad \lambda_{k} v_{k}, s_{m}^{+}, s_{n}^{-} \geq 0
\end{aligned}
$$

Under CRS model, $\phi_{k}^{C R S}$ represents the TE of the $k$-th DMU. The inputs of the $k$-th DMU are multiplied by parameter $\phi_{k}^{C R S}$ to minimise them by the smallest possible factor, based on the constraint that the original output bundle must still be able to be produced by using these reduced inputs. The virtual DMU is created so that each sample can be used in other sample and the comparison can be made to identify the difference between virtual DMU and the real DMU. Under the 
Hafezali Iqbal Hussain, Fakarudin Kamarudin, Nazratul Aina Mohamad Anwar, Fadzlan Sufian, Azlan Ali, Mohd Haizam

Saudi. Social Globalisation and Efficiency of Microfinance Institutions Nexus: Empirical Evidence on Financial and ...

CRS approach $\phi_{k}^{C R S}$, the DMU's output and input denoted as $y_{0}^{m}$ and $x_{o}^{n}$; while the DMU's output and input slacks denoted as $s_{m}^{+}$and $s_{n}^{-}$, respectively. Hence, the DMU is considered as fully TE, with the conditions that the $\phi_{k}^{C R S}$ equals to 1 and there is no output and input slacks.

\section{The Variable Returns to Scale Model and Scale Efficiency under the BCC Model}

\section{The Variable Returns to Scale Model}

The variable returns to the scale (VRS) approach under the BCC DEA Model can be applied to eradicate this issue, by imposing an additional convexity constraint $\sum_{k=1}^{K} v_{k}=1$ to Equation (1). Under VRS approach, the TE scores can be divided into two components, which are pure technical efficiency (PTE) and scale efficiency (ScE), by using model Equation (3) as below:

$$
\begin{array}{ll}
\operatorname{DEA}^{\mathrm{L}}(x, y)=\operatorname{Min} \phi_{k}^{V R S} \mid\left[\phi_{k}^{V R S} \geq 0\right] \\
\text { s.t. } \sum_{k=1}^{K} \lambda_{k} y_{k}^{m}-s_{m}^{+}=y_{o}^{m}, \mathrm{~m}=1, \ldots, \mathrm{M} \\
\quad \sum_{k=1}^{K} v_{k} x_{k}^{n}+s_{n}^{-}=x_{o}^{n}, \mathrm{n}=1, \ldots, \mathrm{N} \\
\quad \sum_{k=1}^{K} v_{k}=1 ; k=1, \ldots, K \\
\quad \lambda_{k} v_{k}, s_{m}^{+}, s_{n}^{-} \geq 0
\end{array}
$$

Under the VRS approach, $\emptyset_{k}^{V R S}$ represents the PTE of the $k$-th DMU that develops a convex monotone hull of intersecting planes that encompass the data points more strongly as compared to the CRS conical hull.

\section{Calculation of Scale Efficiencies}

$\mathrm{ScE}$ is a measurement to investigate the effect of the size of DMU on the efficiency of the system and identify the inefficiency due to the inappropriate size of DMU. Equation (4) exhibits the model of ScE scores of the $k$-th DMU, which is shown below:

$$
\mathrm{ScE}_{k}=\frac{T E}{P T E}=\frac{\phi_{k}^{C R S}}{\phi_{k}^{V R S}}
$$

The DMU is $\mathrm{ScE}$ or CRS when the $\mathrm{ScE}_{k}$ achieves 1, whereas the DMU is scale inefficiency (SIE) if the $\mathrm{ScE}_{k}$ is less than 1 . The ScE scores can be obtained by carrying out both a CRS and a VRS DEA on the same data. The difference in two TE scores of DMU indicates the SIE of DMU, which can be assessed from the difference between the TE score and PTE score.

\section{Inputs, Outputs, Approaches and Choice of Variables}

According to Sealey and Lindley (1977), the production approach and intermediation approach are the two main methods that are widely stated in the MFIs theory literature. Under the production approach, MFIs are treated as the production units, which utilise the inputs, such as the assets, capital, labor and personnel, to produce the outputs like loans, deposits and other financial services (Haq et al., 2010; Bassem, 2008). MFIs will complete the transactions on deposit accounts, process the documents and provide the financial services to their customers. Some of the previous studies reported that the employed asset, personnel and operating costs can be the inputs for producing the loan portfolios, while the financial revenue and the number of active borrowers can be the outputs to measure the production efficiency of MFIs (Bassem, 2008; Ahmad, 2011).

Under intermediation approach, MFIs are treated as the intermediaries between the savers and the borrowers, which provide the loans especially to the poor community, in order to achieve profit or non-profit purpose (Chu \& Lim, 1998). Under this approach, the input will be the deposits from the surplus units, while the output will be the loans to the deficit units. In this research, the intermediation approach, which is also known as asset approach will be applied due to the reason that MFIs will be more appropriate to be considered as the financial aid entities (Aghimien et al., 2016). The efficiencies of MFIs are modelled as social efficiency and financial efficiency as shown in Table 1, with the list of input and output variables.

According to Cooper et al. (2002), there is a rule to be complied with in choosing the input and output items. The rough rule of thumb emphasises the guidelines in choosing the

\begin{tabular}{|c|c|c|c|}
\hline Efficiency & Variable & Variable name & Description \\
\hline \multirow{5}{*}{$\begin{array}{l}\text { Social } \\
\text { Efficiency }\end{array}$} & \multirow{3}{*}{ Input } & Asset & Total asset available to MFI from capital or borrowings \\
\hline & & Operating Expenses & All operating expenses \\
\hline & & Personnel & Salaries of the staffs \\
\hline & \multirow[t]{2}{*}{ Output } & Average Loan Balance & $\begin{array}{l}\text { Average loan balance per borrower over Gross National } \\
\text { Income (GNI) per capita }\end{array}$ \\
\hline & & Number of Borrowers & Number of actual borrowers \\
\hline \multirow{4}{*}{$\begin{array}{l}\text { Financial } \\
\text { Efficiency }\end{array}$} & \multirow{3}{*}{ Input } & Asset & Total asset available to MFI from capital or borrowings \\
\hline & & Operating Expenses & All operating expenses \\
\hline & & Personnel & Salaries of the staffs \\
\hline & Output & Financial Revenue & $\begin{array}{l}\text { Total revenue from gross loan portfolio including margin } \\
\text { charge for loans }\end{array}$ \\
\hline
\end{tabular}
inputs and outputs, which is stated below:

$$
\begin{aligned}
& n \geq \max \{m \times s, 3 \times(m+s)\} \\
& \text { where: } \\
& n=\text { the number of DMUs } \\
& m=\text { the number of inputs } \\
& s=\text { the number of outputs. }
\end{aligned}
$$

Table 1

Social Efficiency and Financial Efficiency (Input and Output Variables) 


\section{Multiple Regression Analysis}

In this research, OLS regression method is adopted in the second stage regression analysis to examine the impacts of MFIs specific determinants, macroeconomic factors and social globalisation components on the financial efficiency and social efficiency of MFIs (Banker \& Natarajan, 2005 \& 2008; Banker et al., 2010; Chen et al., 2018; Chih et al., 2018; Teto et al., 2019). The regression models are being estimated by applying White (1980) transformation (McDonald, 2009). The White test is a statistical test that is robust to the heteroscedasticity, in which it shows a constant variance for the error variables. In the second stage regression analysis, the DEA efficiency scores is applied as a dependent variable for the distribution of the disturbances. By applying the financial and social efficiency scores as the dependent variables, the baseline regression model is being estimated as shown below:

$$
\begin{aligned}
& \text { Effeciency }_{i, t}=\beta_{0}+\beta_{1} \ln T A+\beta_{2} \ln A g e+ \\
& \beta_{3} \ln R O A+\beta_{4} \ln D T E+\beta_{5} \ln G D P+\beta_{6} \ln I N F+ \\
& \beta_{7} \ln P E R S C O N T+\beta_{8} \ln I N F O F L O W+ \\
& \beta_{9} \operatorname{lnCULPROX}+\Sigma_{i, t}
\end{aligned}
$$

From Equation 6 above, efficiency stands for the financial and social efficiency scores derived from the DEA method. MFIs characteristics is a vector of MFIs specific determinants that consist of size of MFIs $(\operatorname{lnTA})$, age of MFIs (lnAge), profitability of MFIs (lnROA) and debt to equity (lnDTE). Macroeconomics is a set of macroeconomic variables that comprise of economic growth (lnGDP) and inflation rate (lnINF). Social globalisation is a set of KOF Globalisation Index that includes data on personal contacts (lnPERSCONT), information flows (lnINFOFLOW) and cultural proximity (lnCULPROX). $\varepsilon$ is the error term, subscript $\mathrm{i}$ represents the individual MFIs and subscript $t$ indicates the time period.
In order to avoid the multicollinearity problem, a stepwise regression is performed instead of the simultaneous regression models. Moreover, some of the researchers tend to apply the log-linear form in the regression analysis in order to improve the goodness of fit of the regression models and to reduce the occurrence of the multicollinearity problem (De Bandt \& Davis, 2000; Staikouras et al., 2008).

To sum up, DEA approach will be applied in the first stage to investigate the efficiency of MFIs during the study period from year 2010 to 2017. In the second stage, we apply multiple panel regression analysis framework, in which Breusch Pagan (BP) and Lagrangian Multiplier (LM) Chi-Square $\left(\chi^{2}\right)$ test is conducted in order to determine the appropriate model to be used, either pull Ordinary Least Square (OLS) or panel Generalized Least Square (GLS) model (Shafai et al., 2019; Sell, 2020). In addition, a subsequent test, which is Hausman test will be conducted to select the most appropriate estimation method, either Fixed Effect (FE) model or Random Effect (RE) model to be applied, provided that panel GLS model is determined to be applied in the prior test.

\section{Description of Variables Used in the Multiple Panel Regression Models}

There are four MFI specific determinants and two macroeconomic factors involved in the multiple panel regression models. To further investigate the relationship between the social globalisation and the efficiency of MFIs, the personal contacts (InPERSCONT), information flows (lnINFOFLOW) and cultural proximity (lnCULPROX) variables will be included. The components are measured by the KOF Globalisation Index with the scale from 1 to 100 , where the higher value of the score indicates the more globalised the country towards the efficiency of MFIs. Table 2 provide the details description of MFI specific,

\begin{tabular}{|c|c|c|c|}
\hline Variables & Note & References & Data Sources \\
\hline \multicolumn{4}{|c|}{ MFI Specific: } \\
\hline $\operatorname{lnTA}$ & $\begin{array}{l}\text { A proxy of MFI size computed } \\
\text { as the natural logarithm of total } \\
\text { MFI assets }\end{array}$ & $\begin{array}{l}\text { Alhassan (2015), Yazdanfar (2013), Stiroh } \\
\text { and Rumble (2006), Pasiouras and Kosmidou } \\
\text { (2007), Girardone et al. (2004) }\end{array}$ & $\begin{array}{l}\text { Microfinance Information } \\
\text { Exchange (MIX) market } \\
\text { www.mixmarket.org }\end{array}$ \\
\hline lnAge & $\begin{array}{l}\text { A proxy of MFI age computed as } \\
\text { the natural logarithm of total } \\
\text { number of year operation of MFI }\end{array}$ & $\begin{array}{l}\text { Abayie et al (2011), Lebovics et al (2016), } \\
\text { Yazdanfar (2013), Muda et al (2013), Hossain } \\
\text { and Khan (2016) }\end{array}$ & $\begin{array}{l}\text { Microfinance Information } \\
\text { Exchange (MIX) market } \\
\text { www.mixmarket.org }\end{array}$ \\
\hline $\operatorname{lnROA}$ & $\begin{array}{l}\text { A proxy of profitability } \\
\text { computed as the natural } \\
\text { logarithm of the ratio of profits } \\
\text { or net income divided by total } \\
\text { assets }\end{array}$ & $\begin{array}{l}\text { Wijesiri and Meoli (2015), Mia and Ben } \\
\text { Soltane (2016), Wijesiri et al. (2015), Zeller } \\
\text { and Meyer (2002), Lebovics et al. (2016) }\end{array}$ & $\begin{array}{l}\text { Microfinance Information } \\
\text { Exchange (MIX) market } \\
\text { www.mixmarket.org }\end{array}$ \\
\hline $\operatorname{lnDTE}$ & $\begin{array}{l}\text { A proxy of leverage computed as } \\
\text { the natural logarithm of the ratio } \\
\text { of total debts divided by total } \\
\text { equity }\end{array}$ & $\begin{array}{l}\text { Abrar and Javaid (2016), Hussain et al. } \\
\text { (2018), Kyereboah-Coleman (2007), Mia and } \\
\text { Ben Soltane (2016), Pradhan and Khadka } \\
\text { (2017), Ebaid (2009) }\end{array}$ & $\begin{array}{l}\text { Microfinance Information } \\
\text { Exchange (MIX) market } \\
\text { www.mixmarket.org }\end{array}$ \\
\hline \multicolumn{4}{|c|}{ Macroeconomics: } \\
\hline $\operatorname{lnGDP}$ & $\begin{array}{l}\text { A proxy of economic growth } \\
\text { computed as the natural } \\
\text { logarithm of the national gross } \\
\text { domestic product }\end{array}$ & $\begin{array}{l}\text { Muda et al. (2013), Al-Harbi (2019), } \\
\text { Thoraneenitiyan and Avkiran (2009) and } \\
\text { Sufian and Habibullah (2010), Ashenafi and } \\
\text { Kingawa (2018) }\end{array}$ & $\begin{array}{l}\text { International Monetary Fund } \\
\text { (IMF) } \\
\text { www.imf.org }\end{array}$ \\
\hline
\end{tabular}
macroeconomic and social globalisation variables

Table 2

Description of MFI Specific, Macroeconomic and Social Globalisation Variables 
Hafezali Iqbal Hussain, Fakarudin Kamarudin, Nazratul Aina Mohamad Anwar, Fadzlan Sufian, Azlan Ali, Mohd Haizam Saudi. Social Globalisation and Efficiency of Microfinance Institutions Nexus: Empirical Evidence on Financial and ...

\begin{tabular}{|c|c|c|c|}
\hline Variables & Note & References & Data Sources \\
\hline \multicolumn{4}{|c|}{ MFI Specific: } \\
\hline $\operatorname{lnINF}$ & $\begin{array}{l}\text { A proxy of consumer price index } \\
\text { computed as the natural } \\
\text { logarithm of the consumer price } \\
\text { index }\end{array}$ & $\begin{array}{l}\text { Tan and Floros (2012), Sufian and Habibullah } \\
\text { (2012b), Kamarudin et al. (2019), Muda et al. } \\
\text { (2013), Mia and Ben Soltane (2016) }\end{array}$ & $\begin{array}{l}\text { International Monetary Fund } \\
\text { (IMF) } \\
\text { www.imf.org }\end{array}$ \\
\hline \multicolumn{4}{|c|}{ Social Globalisation: } \\
\hline $\begin{array}{l}\ln \text { PERSCO } \\
\text { NT }\end{array}$ & $\begin{array}{l}\text { The extent to which the } \\
\text { communications between people } \\
\text { across the world through daily } \\
\text { physical interactions, mailings } \\
\text { and telecommunications }\end{array}$ & $\begin{array}{l}\text { Sufian and Habibullah (2012a), Sufian, } \\
\text { Kamarudin and Md. Nassir (2017), Sufian and } \\
\text { Kamarudin (2016), Nguyen and Nguyen } \\
\text { (2018), Dreher (2006) }\end{array}$ & $\begin{array}{l}\text { KOF Globalisation Index } 2019 \\
\text { https://kof.ethz.ch/en/ }\end{array}$ \\
\hline $\begin{array}{l}\text { lnINFOFL } \\
\text { OW }\end{array}$ & $\begin{array}{l}\text { The spread of ideas and } \\
\text { information across the countries } \\
\text { around the world and between } \\
\text { formal and informal economies } \\
\text { through the internet, television } \\
\text { and newspaper }\end{array}$ & $\begin{array}{l}\text { Sufian, Kamarudin and Md. Nassir (2017), } \\
\text { Badenhorst-Weiss et al. (2013), Sufian and } \\
\text { Kamarudin (2016), Sufian and Habibullah } \\
\text { (2012a), Nguyen and Nguyen (2018) }\end{array}$ & $\begin{array}{l}\text { KOF Globalisation Index } 2019 \\
\text { https://kof.ethz.ch/en/ }\end{array}$ \\
\hline $\begin{array}{l}\operatorname{lnCULPR} \\
\text { OX }\end{array}$ & $\begin{array}{l}\text { The diffusion of cultures and } \\
\text { social norms in the country }\end{array}$ & $\begin{array}{l}\text { Sufian and Habibullah (2012b), Accetturo et } \\
\text { al. (2019), Fisman et al. (2017), Sufian and } \\
\text { Kamarudin (2016), Nguyen and Nguyen } \\
\text { (2018) }\end{array}$ & $\begin{array}{l}\text { KOF Globalisation Index } 2019 \\
\text { https://kof.ethz.ch/en/ }\end{array}$ \\
\hline
\end{tabular}

\section{Results and Discussion}

\section{Social and Financial Efficiencies of MFIs}

Table 3 and Table 4 display the mean scores of MFIs in the terms of financial efficiency (FE) and social efficiency (SE). There are total of 9 panels in each table, in which the panels represent year 2010 (Panel A), year 2011 (Panel B), 2012 (Panel C), year 2013 (Panel D), year 2014 (Panel E), 2015 (Panel F), 2016 (Panel G), 2017 (Panel H) and all years (Panel I) in the context of financial efficiency [Table 3] and social efficiency [Table 4].

From the financial efficiency aspect in Table 3, the Technical Efficiency (TE) mean for MFI had been increased from year $2010(76.3 \%)$ to 2011 (76.7\%). In the subsequent year, a decreasing trend had been discovered in the TE mean for MFI, in which the TE mean in year 2012 and 2013 are $74.7 \%$ and $72.9 \%$ respectively. Although there was an increase in the TE mean in year 2014 (74.4\%), but the TE mean decreased to $72.9 \%$ in year 2015. A rebound for the TE mean had been found in the subsequent years, showed that the TE mean increased to $75.5 \%$ and $76 \%$ in the respective year of 2016 and 2017.

The overall TE mean in financial efficiency for all MFIs (Panel I), had shown an average of $74.9 \%$ with an average input waste of $25.1 \%$ in Table 3. The Scale Efficiency (ScE) mean was being recorded as $94.5 \%$, which implied that $\mathrm{ScE}$ contributed merely $5.5 \%$ to the inefficiency of MFIs from the financial efficiency perspective, while the major contributor for the financial inefficiency is Pure Technical Efficiency (PTE), with the inefficiency of $20.3 \%$. These results claimed that $\mathrm{PTE}$, which referred to the managerial factors, was the main cause for the inefficiency of MFIs from the financial efficiency perspective. Additionally, these results also suggested that MFIs could reduce $25.1 \%$ of the current inputs to reach the current output productively.

From the social efficiency aspect, Table 4 illustrated that the TE mean had been increased from year 2010 to 2012 , in which the TE mean were $38.5 \%, 38.6 \%$ and $40.7 \%$ in year 2010, 2011 and 2012 respectively. There was a continuous decline in TE mean in year 2013 and 2014, with the TE mean of $39.5 \%$ and $38.6 \%$ respectively. Although there is a slight increase for TE mean in year 2015 with the recorded TE mean of $38.8 \%$, but TE mean experienced a slight decrease to $38.4 \%$ in year 2016 before heading to an increase of TE mean in year 2017, with the recorded TE mean of $39 \%$.

Meanwhile, the overall perspective of social efficiency for all MFIs in all study years, Panel I in Table 4 showed that the mean for Technical Efficiency (TE), Pure Technical Efficiency (PTE) and Scale Efficiency (ScE) were $39 \%$, $46.4 \%$ and $85.9 \%$ respectively. From these results, the overall average of MFIs efficiency level from the social efficiency perspective was low, with the recorded TE mean of $39 \%$ while the remaining $61 \%$ indicated the inefficiency of MFIs. The results claimed that the average PTE that referred to the pure managerial factors had the most significant contribution to the inefficiency of social efficiency of MFIs as the PTE was merely efficient at $46.4 \%$ with the input waste of $53.6 \%$, while ScE mean was $85.9 \%$ with the mere $14.1 \%$ input waste. According to the results shown, MFIs could reduce an average $61 \%$ of their inputs to produce the same amount of current outputs, which denote that MFIs require merely $39 \%$ of current input to produce the same amount of outputs when MFIs are fully efficient.

In a nutshell, the results concluded that the main contributor of MFIs inefficiency is due to managerial inefficiency in MFIs during the study period. The management of MFIs failed to fully utilise their resources and lead to the creation of resource waste even though MFIs had achieved a relative optimal scale in the operation. 
Summary Statistics of MFIs Financial Efficiency Scores

\begin{tabular}{|c|c|c|c|c|c|}
\hline Financial Efficiency & No. DMUs & Min & Max & Average & Std. Dev. \\
\hline \multicolumn{6}{|c|}{ Panel A: All MFIs 2010} \\
\hline Technical Efficiency & 88 & 0.323 & 1.000 & 0.763 & 0.139 \\
\hline Pure Technical Efficiency & 88 & 0.526 & 1.000 & 0.810 & 0.138 \\
\hline Scale Efficiency & 88 & 0.323 & 1.000 & 0.946 & 0.083 \\
\hline \multicolumn{6}{|c|}{ Panel B: All MFIs 2011} \\
\hline Technical Efficiency & 88 & 0.296 & 1.000 & 0.767 & 0.146 \\
\hline Pure Technical Efficiency & 88 & 0.482 & 1.000 & 0.801 & 0.141 \\
\hline Scale Efficiency & 88 & 0.296 & 1.000 & 0.960 & 0.081 \\
\hline \multicolumn{6}{|c|}{ Panel C: All MFIs 2012} \\
\hline Technical Efficiency & 88 & 0.300 & 1.000 & 0.747 & 0.141 \\
\hline Pure Technical Efficiency & 88 & 0.529 & 1.000 & 0.785 & 0.144 \\
\hline Scale Efficiency & 88 & 0.300 & 1.000 & 0.956 & 0.085 \\
\hline \multicolumn{6}{|c|}{ Panel D: All MFIs 2013} \\
\hline Technical Efficiency & 88 & 0.296 & 1.000 & 0.729 & 0.152 \\
\hline Pure Technical Efficiency & 88 & 0.517 & 1.000 & 0.764 & 0.151 \\
\hline Scale Efficiency & 88 & 0.296 & 1.000 & 0.957 & 0.091 \\
\hline \multicolumn{6}{|c|}{ Panel E: All MFIs 2014} \\
\hline Technical Efficiency & 88 & 0.313 & 1.000 & 0.744 & 0.140 \\
\hline Pure Technical Efficiency & 88 & 0.522 & 1.000 & 0.805 & 0.146 \\
\hline Scale Efficiency & 88 & 0.313 & 1.000 & 0.930 & 0.090 \\
\hline \multicolumn{6}{|c|}{ Panel F: All MFIs 2015} \\
\hline Technical Efficiency & 88 & 0.289 & 1.000 & 0.729 & 0.148 \\
\hline Pure Technical Efficiency & 88 & 0.366 & 1.000 & 0.797 & 0.152 \\
\hline Scale Efficiency & 88 & 0.289 & 1.000 & 0.919 & 0.097 \\
\hline \multicolumn{6}{|c|}{ Panel G: All MFIs 2016} \\
\hline Technical Efficiency & 88 & 0.304 & 1.000 & 0.755 & 0.147 \\
\hline Pure Technical Efficiency & 88 & 0.510 & 1.000 & 0.802 & 0.145 \\
\hline Scale Efficiency & 88 & 0.304 & 1.000 & 0.944 & 0.084 \\
\hline \multicolumn{6}{|c|}{ Panel H: All MFIs 2017} \\
\hline Technical Efficiency & 88 & 0.330 & 1.000 & 0.760 & 0.144 \\
\hline Pure Technical Efficiency & 88 & 0.348 & 1.000 & 0.809 & 0.146 \\
\hline Scale Efficiency & 88 & 0.330 & 1.000 & 0.944 & 0.086 \\
\hline \multicolumn{6}{|c|}{ Panel I: All MFIs All Years } \\
\hline Technical Efficiency & 88 & 0.289 & 1.000 & 0.749 & 0.144 \\
\hline Pure Technical Efficiency & 88 & 0.348 & 1.000 & 0.797 & 0.145 \\
\hline Scale Efficiency & 88 & 0.289 & 1.000 & 0.945 & 0.088 \\
\hline
\end{tabular}

Summary Statistics of MFIs Social Efficiency Scores

\begin{tabular}{|c|c|c|c|c|c|}
\hline Social Efficiency & No. DMUs & Min & Max & Average & Std. Dev. \\
\hline \multicolumn{6}{|c|}{ Panel A: All MFIs 2010} \\
\hline Technical Efficiency & 88 & 0.067 & 1.000 & 0.385 & 0.221 \\
\hline Pure Technical Efficiency & 88 & 0.077 & 1.000 & 0.464 & 0.260 \\
\hline Scale Efficiency & 88 & 0.428 & 1.000 & 0.847 & 0.146 \\
\hline \multicolumn{6}{|c|}{ Panel B: All MFIs 2011} \\
\hline Technical Efficiency & 88 & 0.087 & 1.000 & 0.386 & 0.226 \\
\hline Pure Technical Efficiency & 88 & 0.099 & 1.000 & 0.444 & 0.260 \\
\hline Scale Efficiency & 88 & 0.426 & 1.000 & 0.886 & 0.119 \\
\hline \multicolumn{6}{|c|}{ Panel C: All MFIs 2012} \\
\hline Technical Efficiency & 88 & 0.088 & 1.000 & 0.407 & 0.236 \\
\hline Pure Technical Efficiency & 88 & 0.095 & 1.000 & 0.474 & 0.270 \\
\hline Scale Efficiency & 88 & 0.420 & 1.000 & 0.878 & 0.134 \\
\hline \multicolumn{6}{|c|}{ Panel D: All MFIs 2013} \\
\hline Technical Efficiency & 88 & 0.061 & 1.000 & 0.395 & 0.229 \\
\hline Pure Technical Efficiency & 88 & 0.071 & 1.000 & 0.464 & 0.258 \\
\hline Scale Efficiency & 88 & 0.472 & 1.000 & 0.859 & 0.130 \\
\hline \multicolumn{6}{|c|}{ Panel E: All MFIs 2014} \\
\hline Technical Efficiency & 88 & 0.053 & 1.000 & 0.386 & 0.226 \\
\hline Pure Technical Efficiency & 88 & 0.065 & 1.000 & 0.459 & 0.261 \\
\hline
\end{tabular}


Hafezali Iqbal Hussain, Fakarudin Kamarudin, Nazratul Aina Mohamad Anwar, Fadzlan Sufian, Azlan Ali, Mohd Haizam

Saudi. Social Globalisation and Efficiency of Microfinance Institutions Nexus: Empirical Evidence on Financial and ...

\begin{tabular}{|l|c|c|c|c|c|}
\hline \multicolumn{1}{|c|}{ Social Efficiency } & No. DMUs & Min & Max & Average & Std. Dev. \\
\hline Scale Efficiency & 88 & 0.445 & 1.000 & 0.855 & 0.137 \\
\hline \multicolumn{7}{|c|}{ Panel F: All MFIs 2015 } \\
\hline Technical Efficiency & 88 & 0.052 & 1.000 & 0.388 & 0.223 \\
\hline Pure Technical Efficiency & 88 & 0.072 & 1.000 & 0.462 & 0.260 \\
\hline Scale Efficiency & 88 & 0.457 & 1.000 & 0.856 & 0.141 \\
\hline \multicolumn{7}{|c|}{ Panel G: All MFIs 2016 } \\
\hline Technical Efficiency & 88 & 0.048 & 1.000 & 0.384 & 0.224 \\
\hline Pure Technical Efficiency & 88 & 0.066 & 1.000 & 0.468 & 0.273 \\
\hline Scale Efficiency & 88 & 0.386 & 1.000 & 0.845 & 0.155 \\
\hline \multicolumn{7}{|c|}{ Panel H: All MFIs 2017 } \\
\hline Technical Efficiency & 88 & 0.050 & 1.000 & 0.390 & 0.221 \\
\hline Pure Technical Efficiency & 88 & 0.068 & 1.000 & 0.476 & 0.264 \\
\hline Scale Efficiency & 88 & 0.388 & 1.000 & 0.842 & 0.156 \\
\hline \multicolumn{7}{|c|}{ Panel I: All MFIs All Years } & \multicolumn{4}{|c|}{} \\
\hline Technical Efficiency & 88 & 0.048 & 1.000 & 0.390 & 0.225 \\
\hline Pure Technical Efficiency & 88 & 0.065 & 1.000 & 0.464 & 0.262 \\
\hline Scale Efficiency & 88 & 0.386 & 1.000 & 0.859 & 0.140 \\
\hline
\end{tabular}

\section{Robustness Test}

A robustness test is essential to determine the gap and significance level of the findings for TE, PTE and SE after analysing the financial efficiency and social efficiency of the MFIs. According to Coakes and Steed (2003), MannWhitney [Wilcoxon] is the most appropriate test to be carried out for the two independent samples from the population that consists of the same distribution. By applying Mann-Whitney test, the data could violate the stringent assumptions of the independent group in t-test. Sufian and Kamarudin (2015) suggested that a series of robustness tests such as parametric (t-test) and non-parametric (Mann-Whitney and KruskallWallis) can be implemented in order to attain the results with high robustness level. Therefore, both parametric (t-test) and non-parametric (Mann-Whitney and Kruskall-Wallis) robustness tests were carried out in this study. Table 5 illustrates the robustness tests for MFIs.

Based on the results shown in Table 5, parametric t-test suggests that the financial efficiency of MFIs exhibits higher TE mean as compared to social efficiency $(0.7492>0.3901)$ and significantly different at $1 \%$. Similar results are obtained for PTE and ScE in which the financial efficiency tends to have higher mean in PTE $(0.7965>0.4639)$ and $\mathrm{ScE}$ $(0.9446>0.8587)$ as compared to social efficiency and significantly different at $1 \%$. These results from parametric $t-$ test are well supported by the non-parametric Mann-Whitney (Wilcoxon) and Kruskal-Wallis tests. Therefore, it can be said that the results are consistent for both parametric and nonparametric tests.

Table 5

Summary Statistics of MFIs Social Efficiency Scores

\begin{tabular}{|c|c|c|c|c|c|c|}
\hline \multirow{4}{*}{ Test statistic } & \multicolumn{2}{|c|}{ Parametric test } & \multicolumn{4}{|c|}{ Non-parametric test } \\
\hline & \multicolumn{2}{|c|}{ t-test } & \multicolumn{2}{|c|}{ Mann-Whitney test } & \multicolumn{2}{|c|}{ Kruskall-Wallis test } \\
\hline & \multicolumn{2}{|c|}{$t(\operatorname{Prb}>t)$} & \multicolumn{2}{|c|}{$z(\operatorname{Prb}>z)$} & \multicolumn{2}{|c|}{$x^{2}\left(\operatorname{Prb}>x^{2}\right)$} \\
\hline & Mean & $\mathbf{t}$ & Mean rank & $\mathbf{Z}$ & Mean rank & $\mathbf{x}^{2}$ \\
\hline \multicolumn{7}{|c|}{ Technical Efficiency } \\
\hline Social Efficiency & 0.3901 & $35.654^{\mathrm{a}}$ & 425.80 & $-25.723^{a}$ & 425.80 & $661.670^{\mathrm{a}}$ \\
\hline Financial Efficiency & 0.7492 & & 983.20 & & 983.20 & \\
\hline \multicolumn{7}{|c|}{ Pure Technical Efficiency } \\
\hline Social Efficiency & 0.4639 & $29.429^{\mathrm{a}}$ & 460.80 & $-22.525^{a}$ & 460.80 & $507.373^{a}$ \\
\hline Financial Efficiency & 0.7965 & & 948.20 & & 948.20 & \\
\hline \multicolumn{7}{|c|}{ Scale Efficiency } \\
\hline Social Efficiency & 0.8587 & $13.758^{\mathrm{a}}$ & 556.80 & $-13.634^{a}$ & 556.80 & $185.889^{a}$ \\
\hline Financial Efficiency & 0.9446 & & 852.20 & & 852.20 & \\
\hline
\end{tabular}

Note: $a, b, c$ indicates significance at $1 \%, 5 \%$ and $10 \%$ levels respectively.

\section{Determinants of Efficiency Level in MFIs}

A total of 5 models regarding the financial efficiency and social efficiency of MFIs during the study period had been constructed, analysed and shown in Table 6 and Table 7. Model 1 had been built as a baseline regression model that merely consists of MFIs specific determinant variables, namely size of MFIs ( $\ln$ TA), total years of operation for MFIs (lnAGE), profitability of MFIs measured by the formula of return on assets (lnROA), leverage level of MFIs measured by the formula of debt to equity ratio (lnDTE).
Next, macroeconomic variables which are economic growth (lnGDP) and inflation rate measured by Consumer Price Index (lnINF) are added with MFIs specific determinant variables stated in Model 1 to form Model 2. For the following models in the regression analysis, social globalisation components, namely personal contacts, information flows and cultural proximity had been included in the models. Both MFIs specific determinant variables and macroeconomic variables are existed in Model 3, Model 4 
and Model 5, with additional social globalisation, personal contacts, information flows and cultural proximity in the respective model.

In the preliminary stage, all 5 models for both financial and social efficiency indicated that the significant level is $5 \%$ or lower in p-value of Breusch Pagan and Lagrangian Multiplier Chi-Square (BP and LM x2) test. Hence, panel data GLS will be more appropriate to be applied for all 5 models in both financial and social efficiency of MFIs, instead of using pooled data OLS. Next, Hausman test had been conducted to determine the most suitable panal data GLS methods to be applied for each model under regression analysis. Kamarudin, Sufian and Nassir (2016) stated that Hausman test can be carried out to determine the suitability of Fixed Effect Model (FEM) and Random Effect Model (REM) to be applied, with the conditions that FEM is more appropriate to be used in the model that has the significant levels at $1 \%$ to $5 \%$, whereas REM is more appropriate to be applied in the models that show the significant levels at $10 \%$. Therefore, REM will be applied to all models for both financial efficiency and social efficiency regression analysis as all of the models illustrate the significant levels for Hausman test (x2) are $10 \%$ and above.

Based on Table 7, there is a significant negative relationship between total assets (lnTA) and social efficiency of MFIs in all models at $1 \%$ significance level. The larger (smaller) the size of MFIs total assets, the lower (higher) the social efficiency of MFIs. Demirgunes and Ucler (2015) reported that large firms incurred higher operation costs and long term average production costs and thus failed to utilise the resources in providing financial aid to the poor community. This is due to the reason that MFIs allocate more financial resources in paying these costs, and thus reducing the funds and the number of loans to be provided to the poor people, which imply that MFIs fail to achieve social efficiency. This result is well supported by Stiroh and Rumble (2006) and Pasiouras and Kosmidou (2007) as they claimed that larger banks incurred higher management costs, overheads of bureaucratic processes and agency costs, thus reducing the profitability and ability of the banks in granting loans to the poorer. Therefore, it can be concluded that larger banks tend to achieve lower social efficiency.

Besides, the total operation years of MFIs (lnAGE) has a significant negative relationship with financial efficiency and social efficiency of MFIs as shown in Table 6 and Table 7. The significance level of the relationship between age of MFIs and the financial efficiency are $1 \%$ in Model 3, $5 \%$ in Model 2, $10 \%$ in Model 4 and Model 5, while the significance level of the relationship between age of MFIs and the social efficiency is $5 \%$ in Model 2 . These results imply that the older (younger) the age of MFIs, the lower (higher) the financial and social efficiency of MFIs. Muda et al. (2013) claimed that new banks are more profitable as compared to older banks because new banks apply and adapt to the new technologies. Young firms put efforts to discover new processes to eradicate the problems and the continuous learning process will result the reduction of labor and time to current problems, which subsequently lead to better performance of the institutions. Older firms tend to experience the occurrence of obsolescence due to their inability to adapt in the changing business environment whereas senescence happens because of their rigid regulations, routines and structures of the organisation (Coad et al., 2011). As a consequence, younger banks could perform better in achieving both financial and social efficiency, as the bank operation is well performed in generating more revenue from financial efficiency aspect and capable to contribute and help the poorer in obtaining financial aid from social efficiency aspect.

Moreover, a significant positive relationship exists between the profitability of MFIs (lnROA) and financial efficiency of MFIs at $5 \%$ significance level in Model 3. The higher (lower) the profitability of MFIs, the higher (lower) financial efficiency of MFIs. Wijesiri and Meoli (2015) concluded that MFIs with higher ROA are more likely to adapt to technological changes and invest more in innovations as ROA positively associates with the progress in productivity and innovation over a period of time. Therefore, MFIs that achieve greater financial performance from the profitability aspect will have greater total factor productivity (TFP) growth and achieve higher financial efficiency. This result is supported that Mia and Ben Soltane (2016) who discovered that ROA has a significant positive impact on the productivity of the banks.

Furthermore, there is a significant positive relationship between economic growth (lnGDP) and both financial and social efficiency of MFIs. The significance level of the relationship between economic growth and the financial efficiency are $5 \%$ in Model 2, Model 4 and $10 \%$ in Model 5 , while the significance level of the relationship between economic growth and the social efficiency are $1 \%$ in Model 2 and Model 4 and $5 \%$ in Model 3. These results concluded that the higher (lower) the economic growth, the higher (lower) the financial efficiency and social efficiency of MFIs. According to Muda et al. (2013), a growing economy will lead to an increasing demand for banking services and lower risk as compared to bad economy scenario. Al-Harbi (2019) concluded that good economic development leads to higher economic efficiency and better profitability of the bank. During the good economic conditions, people have excessive money to save in the banks and the banks have more capital or financial resources to run the bank business to increase the financial efficiency by generating more income and to provide the financial aid to the poorer, which could increase the social efficiency of the banks. The repayment rate to the banks will be comparably higher in a good economic condition, as the lenders are more capable to make repayment to the banks and thus reducing the loan default rate.

Apart from that, Table 6 exhibits a significant positive relationship between personal contacts (InPERSCONT) and financial efficiency of MFIs at $1 \%$ significance level in Model 3. The more (less) the personal contacts, the higher (lower) the financial efficiency of MFIs. Sufian and Habibullah (2012a) concluded that greater social integration significantly increases the efficiency of the banks. Hao, Li and Marquis (2017) reported that MFIs that operate the bank businesses globally will have broader networks such as international clients and stakeholders. These frequent personal contacts facilitate the communications and create a better understanding and follow-ups between the banks and the stakeholders such as international customers, and thus generate more revenue for the banks from financial efficiency aspect. 
Hafezali Iqbal Hussain, Fakarudin Kamarudin, Nazratul Aina Mohamad Anwar, Fadzlan Sufian, Azlan Ali, Mohd Haizam

Saudi. Social Globalisation and Efficiency of Microfinance Institutions Nexus: Empirical Evidence on Financial and ...

Regression Result on the Financial Efficiency of Microfinance Institutions

Table 6

\begin{tabular}{|c|c|c|c|c|c|c|c|c|c|}
\hline & \multicolumn{3}{|c|}{ Model 1} & \multicolumn{3}{|c|}{ Model 2} & \multicolumn{3}{|c|}{ Model 3} \\
\hline & $\begin{array}{c}\text { Pooled } \\
\text { OLS }\end{array}$ & FEM & REM & $\begin{array}{c}\text { Pooled } \\
\text { OLS }\end{array}$ & FEM & REM & $\begin{array}{c}\text { Pooled } \\
\text { OLS }\end{array}$ & FEM & REM \\
\hline \multirow{2}{*}{ CONSTANT } & -0.090 & -0.081 & 0.039 & $-2.196^{\mathrm{a}}$ & $-2.764^{\mathrm{a}}$ & $-0.746^{\mathrm{c}}$ & $-3.178^{\mathrm{a}}$ & $-3.747^{\mathrm{a}}$ & $-1.986^{\mathrm{a}}$ \\
\hline & $(0.128)$ & $(0.137)$ & $(0.173)$ & $(0.539)$ & $(0.264)$ & $(0.448)$ & $(0.427)$ & $(0.722)$ & $(0.512)$ \\
\hline \multicolumn{10}{|c|}{ MFI's Specific Determinants } \\
\hline \multirow{2}{*}{ LNTA } & $0.029^{\mathrm{a}}$ & $0.029^{\mathrm{a}}$ & -0.015 & $0.030^{\mathrm{a}}$ & $0.030^{\mathrm{a}}$ & -0.011 & $0.031^{\mathrm{a}}$ & $0.030^{\mathrm{b}}$ & -0.007 \\
\hline & $(0.002)$ & $(0.002)$ & $(0.010)$ & $(0.002)$ & $(0.002)$ & $(0.015)$ & $(0.002)$ & $(0.013)$ & $(0.012)$ \\
\hline \multirow{2}{*}{ LNAGE } & $-0.121^{a}$ & $-0.127^{a}$ & -0.015 & $-0.127^{\mathrm{a}}$ & $-0.129^{a}$ & $-0.046^{\mathrm{b}}$ & $-0.131^{a}$ & $-0.129^{a}$ & $-0.112^{a}$ \\
\hline & $(0.009)$ & $(0.008)$ & $(0.024)$ & $(0.009)$ & $(0.008)$ & $(0.019)$ & $(0.009)$ & $(0.042)$ & $(0.028)$ \\
\hline \multirow{2}{*}{ LNROA } & $-0.099^{a}$ & $-0.099^{a}$ & 0.073 & -0.017 & 0.005 & 0.104 & -0.012 & 0.005 & $0.134^{\mathrm{b}}$ \\
\hline & $(0.008)$ & $(0.008)$ & $(0.071)$ & $(0.022)$ & $(0.013)$ & $(0.088)$ & $(0.015)$ & $(0.043)$ & $(0.068)$ \\
\hline \multirow{2}{*}{ LNDER } & -0.027 & -0.026 & -0.013 & -0.033 & -0.028 & -0.014 & -0.031 & -0.028 & -0.011 \\
\hline & $(0.037)$ & $(0.039)$ & $(0.018)$ & $(0.041)$ & $(0.039)$ & $(0.016)$ & $(0.041)$ & $(0.053)$ & $(0.021)$ \\
\hline \multicolumn{10}{|c|}{ Macroeconomics Determinants } \\
\hline \multirow{2}{*}{ LNGDP } & & & & $0.260^{\mathrm{a}}$ & $0.327^{\mathrm{a}}$ & $0.104^{\mathrm{b}}$ & 0.051 & 0.082 & -0.018 \\
\hline & & & & $(0.059)$ & $(0.025)$ & $(0.049)$ & $(0.103)$ & $(0.089)$ & $(0.056)$ \\
\hline \multirow{2}{*}{ LNINF } & & & & 0.004 & $0.013^{\mathrm{a}}$ & 0.002 & $0.005^{\mathrm{b}}$ & 0.004 & 0.003 \\
\hline & & & & $(0.003)$ & $(0.005)$ & $(0.003)$ & $(0.002)$ & $(0.004)$ & $(0.003)$ \\
\hline \multicolumn{10}{|c|}{ Social Globalisation } \\
\hline \multirow{2}{*}{ LNPERSCONT } & & & & & & & $0.710^{\mathrm{b}}$ & $0.789^{\mathrm{a}}$ & $0.627^{\mathrm{a}}$ \\
\hline & & & & & & & $(0.276)$ & $(0.136)$ & $(0.156)$ \\
\hline \multicolumn{10}{|l|}{ LNINFOFLOW } \\
\hline \multicolumn{10}{|l|}{ LNCULPROX } \\
\hline $\mathbf{R}^{2}$ & 0.110 & 0.124 & 0.005 & 0.132 & 0.145 & 0.012 & 0.138 & 0.145 & 0.032 \\
\hline Adj. $\mathbf{R}^{2}$ & 0.104 & 0.110 & -0.001 & 0.124 & 0.129 & 0.003 & 0.129 & 0.128 & 0.022 \\
\hline F-statistic & 21.498 & 8.878 & 0.882 & 17.636 & 9.005 & 1.407 & 15.851 & 8.358 & 3.243 \\
\hline BP \& LM $\chi^{2}$ & \multicolumn{3}{|c|}{$1586.740^{\mathrm{a}}$} & \multicolumn{3}{|c|}{$1576.090^{\mathrm{a}}$} & \multicolumn{3}{|c|}{$1599.070^{\mathrm{a}}$} \\
\hline Hausman $\chi^{2}$ & \multicolumn{3}{|c|}{$8.470^{\mathrm{C}}$} & \multicolumn{3}{|c|}{4.461} & \multicolumn{3}{|c|}{6.184} \\
\hline No. of Obs. & \multicolumn{3}{|c|}{704} & \multicolumn{3}{|c|}{704} & \multicolumn{3}{|c|}{704} \\
\hline Model Used & \multicolumn{3}{|c|}{ REM } & \multicolumn{3}{|c|}{ REM } & \multicolumn{3}{|c|}{ REM } \\
\hline
\end{tabular}

Note: $a, b, c$ indicates significance at $1 \%, 5 \%$ and $10 \%$ levels respectively. Figure in parentheses () are Standard Error.

Table 6

Continued

\begin{tabular}{|c|c|c|c|c|c|c|}
\hline & \multicolumn{3}{|c|}{ Model 4} & \multicolumn{3}{|c|}{ Model 5} \\
\hline & Pooled OLS & FEM & REM & Pooled OLS & FEM & REM \\
\hline \multirow{2}{*}{ CONSTANT } & $-2.631^{a}$ & $3.707^{\mathrm{b}}$ & $-0.961^{\mathrm{c}}$ & $-2.187^{\mathrm{a}}$ & $-2.784^{\mathrm{a}}$ & $-0.684^{\mathrm{c}}$ \\
\hline & $(0.664)$ & $(1.532)$ & $(0.557)$ & $(0.490)$ & $(0.702)$ & $(0.393)$ \\
\hline \multicolumn{7}{|c|}{ MFI's Specific Determinants } \\
\hline \multirow{2}{*}{ LNTA } & $0.030^{\mathrm{a}}$ & $0.030^{\mathrm{b}}$ & -0.011 & $0.030^{\mathrm{a}}$ & $0.030^{\mathrm{b}}$ & -0.011 \\
\hline & $(0.002)$ & $(0.013)$ & $(0.018)$ & $(0.002)$ & $(0.013)$ & $(0.018)$ \\
\hline \multirow{2}{*}{ LNAGE } & $-0.128^{a}$ & $-0.129^{a}$ & $-0.055^{c}$ & $-0.128^{a}$ & $-0.129^{a}$ & $-0.051^{c}$ \\
\hline & $(0.008)$ & $(0.042)$ & $(0.031)$ & $(0.008)$ & $(0.042)$ & $(0.030)$ \\
\hline \multirow{2}{*}{ LNROA } & -0.019 & 0.006 & 0.105 & -0.017 & 0.005 & 0.103 \\
\hline & $(0.022)$ & $(0.043)$ & $(0.162)$ & $(0.021)$ & $(0.043)$ & $(0.163)$ \\
\hline \multirow{2}{*}{ LNDER } & -0.033 & -0.028 & -0.014 & -0.033 & -0.028 & -0.014 \\
\hline & $(0.041)$ & $(0.053)$ & $(0.019)$ & $(0.041)$ & $(0.053)$ & $(0.019)$ \\
\hline \multicolumn{7}{|c|}{ Macroeconomics Determinants } \\
\hline \multirow{2}{*}{ LNGDP } & $0.236^{\mathrm{a}}$ & $0.567^{\mathrm{a}}$ & $0.093^{\mathrm{b}}$ & $0.255^{\mathrm{a}}$ & 0.118 & $0.081^{\mathrm{c}}$ \\
\hline & $(0.069)$ & $(0.083)$ & $(0.037)$ & $(0.077)$ & $(0.120)$ & $(0.041)$ \\
\hline \multirow{2}{*}{ LNINF } & 0.003 & $0.027^{\mathrm{a}}$ & 0.001 & 0.004 & $0.011^{\mathrm{b}}$ & 0.002 \\
\hline & $(0.003)$ & $(0.006)$ & $(0.003)$ & $(0.003)$ & $(0.005)$ & $(0.003)$ \\
\hline \multicolumn{7}{|c|}{ Social Globalisation } \\
\hline \multicolumn{7}{|l|}{ LNPERSCONT } \\
\hline \multirow{2}{*}{ LNINFOFLOW } & 0.150 & $-1.991^{a}$ & 0.074 & & & \\
\hline & $(0.168)$ & $(0.393)$ & $(0.084)$ & & & \\
\hline \multirow{2}{*}{ LNCULPROX } & & & & 0.009 & $0.448^{\mathrm{a}}$ & 0.035 \\
\hline & & & & $(0.145)$ & $(0.133)$ & $(0.064)$ \\
\hline $\mathbf{R}^{2}$ & 0.132 & 0.145 & 0.012 & 0.132 & 0.145 & 0.012 \\
\hline Adj. $R^{2}$ & 0.123 & 0.128 & 0.002 & 0.123 & 0.128 & 0.002 \\
\hline
\end{tabular}




\begin{tabular}{|c|c|c|c|c|c|c|}
\hline & \multicolumn{3}{|c|}{ Model 4 } & \multicolumn{3}{c|}{ Model 5 } \\
\hline & Pooled OLS & FEM & REM & Pooled OLS & FEM & REM \\
\hline F-statistic & 15.134 & 8.368 & 1.236 & 15.095 & 8.364 & 1.217 \\
\hline BP \& LM $\boldsymbol{\chi}^{\mathbf{2}}$ & \multicolumn{3}{|c|}{$1578.130^{\mathrm{a}}$} & \multicolumn{3}{c|}{10.850} \\
\hline Hausman $\boldsymbol{\chi}^{\mathbf{2}}$ & \multicolumn{3}{|c|}{70.656} & \multicolumn{3}{c|}{704} \\
\hline No. of Obs. & \multicolumn{3}{|c|}{ REM } \\
\hline Model Used & \multicolumn{3}{|c|}{ REM } & \multicolumn{3}{c|}{} \\
\hline
\end{tabular}

Note: a, b, c indicates significance at $1 \%, 5 \%$ and $10 \%$ levels respectively. Figure in parentheses () are Standard Error.

Table 7

Regression Result on the Social Efficiency of Microfinance Institutions

\begin{tabular}{|c|c|c|c|c|c|c|c|c|c|}
\hline & \multicolumn{3}{|c|}{ Model 1} & \multicolumn{3}{|c|}{ Model 2} & \multicolumn{3}{|c|}{ Model 3} \\
\hline & $\begin{array}{c}\text { Pooled } \\
\text { OLS }\end{array}$ & FEM & REM & $\begin{array}{c}\text { Pooled } \\
\text { OLS }\end{array}$ & FEM & REM & $\begin{array}{c}\text { Pooled } \\
\text { OLS }\end{array}$ & FEM & REM \\
\hline \multirow[t]{2}{*}{ CONSTANT } & $1.411^{\mathrm{a}}$ & $1.444^{\mathrm{a}}$ & $1.382^{\mathrm{a}}$ & $-3.836^{\mathrm{a}}$ & $-4.997^{\mathrm{a}}$ & -0.212 & $-5.000^{\mathrm{a}}$ & $-6.931^{\mathrm{a}}$ & -0.166 \\
\hline & $(0.448)$ & $(0.490)$ & $(0.408)$ & $(0.804)$ & $(0.651)$ & $(0.695)$ & $(0.799)$ & $(1.204)$ & $(0.996)$ \\
\hline \multicolumn{10}{|c|}{ MFI's Specific Determinants } \\
\hline \multirow{2}{*}{ LNTA } & $-0.118^{\mathrm{a}}$ & $-0.116^{\mathrm{a}}$ & $-0.161^{\mathrm{a}}$ & $-0.113^{\mathrm{a}}$ & $-0.113^{\mathrm{a}}$ & $-0.155^{\mathrm{a}}$ & $-0.113^{\mathrm{a}}$ & $-0.113^{\mathrm{a}}$ & $-0.155^{\mathrm{a}}$ \\
\hline & $(0.003)$ & $(0.004)$ & $(0.024)$ & $(0.003)$ & $(0.004)$ & $(0.049)$ & $(0.004)$ & $(0.004)$ & $(0.024)$ \\
\hline \multirow{2}{*}{ LNAGE } & $-0.341^{\mathrm{a}}$ & $-0.355^{\mathrm{a}}$ & 0.033 & $-0.357^{\mathrm{a}}$ & $-0.358^{\mathrm{a}}$ & $-0.068^{b}$ & $-0.361^{\mathrm{a}}$ & $-0.358^{\mathrm{a}}$ & -0.065 \\
\hline & $(0.017)$ & $(0.018)$ & $(0.049)$ & $(0.019)$ & $(0.018)$ & $(0.035)$ & $(0.018)$ & $(0.018)$ & $(0.080)$ \\
\hline \multirow{2}{*}{ LNROA } & $-0.050^{\mathrm{a}}$ & $-0.049^{\mathrm{a}}$ & -0.060 & $0.155^{\mathrm{a}}$ & $0.200^{\mathrm{a}}$ & 0.017 & $0.160^{\mathrm{a}}$ & $0.200^{\mathrm{a}}$ & 0.016 \\
\hline & $(0.009)$ & $(0.008)$ & $(0.196)$ & $(0.024)$ & $(0.016)$ & $(0.168)$ & $(0.015)$ & $(0.016)$ & $(0.199)$ \\
\hline \multirow{2}{*}{ LNDER } & 0.167 & 0.165 & 0.026 & 0.157 & 0.161 & 0.025 & 0.159 & 0.161 & 0.025 \\
\hline & $(0.120)$ & $(0.129)$ & $(0.031)$ & $(0.132)$ & $(0.130)$ & $(0.053)$ & $(0.131)$ & $(0.130)$ & $(0.031)$ \\
\hline \multicolumn{10}{|c|}{ Macroeconomics Determinants } \\
\hline \multirow{2}{*}{ LNGDP } & & & & $0.648^{\mathrm{a}}$ & $0.785^{\mathrm{a}}$ & $0.228^{\mathrm{a}}$ & $0.400^{\mathrm{a}}$ & 0.304 & $0.231^{\mathrm{b}}$ \\
\hline & & & & $(0.063)$ & $(0.044)$ & $(0.053)$ & $(0.062)$ & $(0.331)$ & $(0.095)$ \\
\hline \multirow{2}{*}{ LNINF } & & & & 0.002 & $0.027^{\mathrm{b}}$ & 0.000 & 0.003 & 0.009 & 0.000 \\
\hline & & & & $(0.004)$ & $(0.012)$ & $(0.002)$ & $(0.002)$ & $(0.015)$ & $(0.005)$ \\
\hline \multicolumn{10}{|c|}{ Social Globalisation } \\
\hline \multirow{2}{*}{ LNPERSCONT } & & & & & & & $0.841^{\mathrm{a}}$ & 1.552 & -0.021 \\
\hline & & & & & & & $(0.184)$ & $(1.023)$ & $(0.316)$ \\
\hline \multirow{2}{*}{\multicolumn{10}{|c|}{ LNINFOFLOW }} \\
\hline & & & & & & & & & \\
\hline \multirow{2}{*}{\multicolumn{10}{|c|}{ LNCULPROX }} \\
\hline & & & & & & & & & \\
\hline $\mathbf{R}^{2}$ & 0.236 & 0.240 & 0.065 & 0.250 & 0.253 & 0.076 & 0.251 & 0.253 & 0.076 \\
\hline Adj. $\mathbf{R}^{2}$ & 0.232 & 0.228 & 0.060 & 0.244 & 0.238 & 0.068 & 0.244 & 0.237 & 0.066 \\
\hline F-statistic & 54.081 & 19.909 & 12.246 & 38.782 & 17.930 & 9.527 & 33.334 & 16.629 & 8.150 \\
\hline BP \& LM $\chi^{2}$ & \multicolumn{3}{|c|}{$2141.140^{\mathrm{a}}$} & \multicolumn{3}{|c|}{$2150.400^{\mathrm{a}}$} & \multicolumn{3}{|c|}{$2154.540^{\mathrm{a}}$} \\
\hline Hausman $\chi^{2}$ & \multicolumn{3}{|c|}{3.241} & \multicolumn{3}{|c|}{1.927} & \multicolumn{3}{|c|}{1.366} \\
\hline No. of Obs. & \multicolumn{3}{|c|}{704} & \multicolumn{3}{|c|}{704} & \multicolumn{3}{|c|}{704} \\
\hline Model Used & \multicolumn{3}{|c|}{ REM } & \multicolumn{3}{|c|}{ REM } & \multicolumn{3}{|c|}{ REM } \\
\hline
\end{tabular}

Note: $a, b, c$ indicates significance at $1 \%, 5 \%$ and $10 \%$ levels respectively. Figure in parentheses () are Standard Error.

Table 7

Continued

\begin{tabular}{|c|c|c|c|c|c|c|}
\hline & \multicolumn{3}{|c|}{ Model 4} & \multicolumn{3}{|c|}{ Model 5} \\
\hline & Pooled OLS & FEM & REM & Pooled OLS & FEM & REM \\
\hline \multirow{2}{*}{ CONSTANT } & $-5.084^{\mathrm{a}}$ & $7.934^{\mathrm{b}}$ & -0.189 & $-3.698^{\mathrm{a}}$ & $-5.015^{\mathrm{a}}$ & -0.004 \\
\hline & $(1.135)$ & $(3.152)$ & $(1.144)$ & $(0.792)$ & $(1.360)$ & $(1.062)$ \\
\hline \multicolumn{7}{|c|}{ MFI's Specific Determinants } \\
\hline \multirow{4}{*}{ LNTA } & $-0.113^{\mathrm{a}}$ & $-0.113^{\mathrm{b}}$ & $-0.155^{\mathrm{a}}$ & $-0.113^{\mathrm{a}}$ & $-0.113^{\mathrm{b}}$ & $-0.153^{\mathrm{a}}$ \\
\hline & $(0.004)$ & $(0.047)$ & $(0.051)$ & $(0.004)$ & $(0.047)$ & $(0.032)$ \\
\hline & \multicolumn{3}{|c|}{ Model 4} & \multicolumn{3}{|c|}{ Model 5} \\
\hline & Pooled OLS & FEM & Pooled OLS & FEM & Pooled OLS & FEM \\
\hline \multirow{2}{*}{ LNAGE } & $-0.360^{\mathrm{a}}$ & $-0.358^{\mathrm{a}}$ & -0.067 & $-0.358^{\mathrm{a}}$ & $-0.358^{a}$ & -0.098 \\
\hline & $(0.018)$ & $(0.128)$ & $(0.061)$ & $(0.018)$ & $(0.128)$ & $(0.087)$ \\
\hline
\end{tabular}


Hafezali Iqbal Hussain, Fakarudin Kamarudin, Nazratul Aina Mohamad Anwar, Fadzlan Sufian, Azlan Ali, Mohd Haizam

Saudi. Social Globalisation and Efficiency of Microfinance Institutions Nexus: Empirical Evidence on Financial and ...

\begin{tabular}{|c|c|c|c|c|c|c|}
\hline \multirow{2}{*}{ LNROA } & $0.149^{\mathrm{a}}$ & $0.201^{\mathrm{b}}$ & 0.017 & $0.150^{\mathrm{a}}$ & $0.200^{\mathrm{b}}$ & 0.019 \\
\hline & $(0.023)$ & $(0.083)$ & $(0.163)$ & $(0.025)$ & $(0.083)$ & $(0.218)$ \\
\hline \multirow{2}{*}{ LNDER } & 0.157 & 0.161 & 0.025 & 0.156 & 0.161 & 0.025 \\
\hline & $(0.132)$ & $(0.108)$ & $(0.054)$ & $(0.132)$ & $(0.108)$ & $(0.031)$ \\
\hline \multicolumn{7}{|c|}{ Macroeconomics Determinants } \\
\hline \multirow{2}{*}{ LNGDP } & $0.579^{\mathrm{a}}$ & $1.264^{\mathrm{a}}$ & $0.229^{\mathrm{a}}$ & $0.565^{\mathrm{a}}$ & $0.601^{\mathrm{a}}$ & 0.145 \\
\hline & $(0.070)$ & $(0.200)$ & $(0.065)$ & $(0.149)$ & $(0.162)$ & $(0.129)$ \\
\hline \multirow{2}{*}{ LNINF } & 0.000 & $0.053^{\mathrm{a}}$ & 0.000 & 0.004 & $0.024^{\mathrm{a}}$ & 0.001 \\
\hline & $(0.004)$ & $(0.013)$ & $(0.003)$ & $(0.005)$ & $(0.007)$ & $(0.003)$ \\
\hline \multicolumn{7}{|c|}{ Social Globalisation } \\
\hline \multicolumn{7}{|l|}{ LNPERSCONT } \\
\hline \multirow{2}{*}{ LNINFOFLOW } & $0.429^{\mathrm{c}}$ & $-3.979^{\mathrm{a}}$ & -0.007 & & & \\
\hline & $(0.253)$ & $(0.998)$ & $(0.187)$ & & & \\
\hline \multirow{2}{*}{ LNCULPROX } & & & & 0.140 & 0.394 & 0.138 \\
\hline & & & & $(0.256)$ & $(0.266)$ & $(0.169)$ \\
\hline $\mathbf{R}^{2}$ & 0.251 & 0.253 & 0.076 & 0.250 & 0.253 & 0.076 \\
\hline Adj. $R^{2}$ & 0.243 & 0.237 & 0.066 & 0.243 & 0.237 & 0.067 \\
\hline F-statistic & 33.237 & 16.635 & 8.151 & 33.204 & 16.627 & 8.219 \\
\hline BP \& LM $\chi^{2}$ & \multicolumn{3}{|c|}{$2152.630^{\mathrm{a}}$} & \multicolumn{3}{|c|}{$2151.470^{\mathrm{a}}$} \\
\hline Hausman $\chi^{2}$ & \multicolumn{3}{|c|}{1.924} & \multicolumn{3}{|c|}{2.015} \\
\hline No. of Obs. & \multicolumn{3}{|c|}{704} & \multicolumn{3}{|c|}{704} \\
\hline Model Used & \multicolumn{3}{|c|}{ REM } & \multicolumn{3}{|c|}{ REM } \\
\hline
\end{tabular}

Note: $a, b, c$ indicates significance at $1 \%, 5 \%$ and $10 \%$ levels respectively. Figure in parentheses () are Standard Error.

\section{Conclusion}

The main objective of this paper is to investigate the impacts of social globalisation components, namely personal contacts, information flows and cultural proximity to the efficiency of MFIs from the financial and social aspects. Besides, this study also determined the potential MFIs specific determinants and macroeconomic factors that may influence the efficiency of MFIs. In this study, the data for a total number of 88 MFIs over the period from year 2010 to 2017 had been collected for the research purpose. And, it can be concluded that the overall financial efficiency is significantly higher than the social efficiency of MFIs.

The results from panel regression analysis revealed that there is a significant negative relationship between total assets (lnTA) and social efficiency of MFIs. Besides, the total operation years of MFIs (lnAGE) has a significant negative relationship with both financial efficiency and social efficiency of MFIs. Moreover, a significant positive relationship exists between the profitability of MFIs (lnROA) and financial efficiency of MFIs. From the macroeconomic condition aspect, there is a significant positive relationship between economic growth (lnGDP) and both financial and social efficiency of MFIs. From the social globalisation aspect, the results exhibited that a significant positive relationship existed between personal contacts (lnPERSCONT) and financial efficiency of MFIs.

This study could identify the important aspects that MFIs should emphasise on, in order to achieve the main objectives of MFIs, namely financial efficiency and social efficiency in providing financial aid to the poor community. The results and findings provide different insights, information and understandings on the contribution of different variables in different aspects, namely MFIs specific determinants, macroeconomic conditions and social globalisation to the financial and social efficiency of MFIs. Based on the information obtained from the study, proper and prompt actions could be implemented in order to achieve the effective results for MFIs from the financial and social efficiency aspects.

First and foremost, the governments or policy makers can establish the effective national policies and strategies, after making a reference on the results and findings of the study. Effective policies and strategies could definitely aid MFIs in growing their businesses and services in providing financial aid or granting loans to the poorer. As a result, the reliable information and recommendations could be reached out to the government and policy makers, so that the formulation of the policy and strategies could produce a fruitful result in helping the nation to attain both financial efficiency and social efficiency. When MFIs have the capabilities to sustain or enlarge the financial services, the poor community can obtain the financial aid from MFIs in order to improve their living.

Furthermore, governments or policymakers can identify any flaws in previously established rules and policies, such as capital requirements, interest rates, and types of investments authorized in MFIs. Governments can take necessary efforts to resolve those challenges in order to ensure that the policies benefit MFIs. Furthermore, more appropriate rules and processes make it easier for the poor to obtain MFI-provided services. As a result, MFIs are managed to provide acceptable financial services to their clients, and efficiency may be increased via the application of appropriate rules.

Besides, this study could aid the investors in monitoring and understanding deeply on the performance of MFIs from financial efficiency and social efficiency aspects. The performances of MFIs are relatively vital for the investors in making the economic or investment decisions as failing to make the right decision could lead to a loss for investors. In order to analyse the valuation of the investment, investors could obtain the information from different sources, including the findings of this study on the financial efficiency and social efficiency of MFIs before making the economic or investment decisions. Undoubtedly, investors 
prefer to invest in the MFIs with higher financial efficiency or higher social efficiency, with the aim to obtain higher returns from their portfolio of investment.

Nonetheless, investors are more concerned with the financial success of MFIs than with the social effects since they are profit-driven. Thus, the MFIs' financial efficiency results are critical to assisting their investment process, since they are able to analyze the MFIs' profitability in the past. Furthermore, this study enables them to uncover particular drivers in MFIs as well as variables in the external environment such as macroeconomic issues and globalisation aspects that may impact MFI earnings.

Last but not least, the researchers who are interested to conduct the related research in the financial industry such as MFIs, could refer the findings of this study and improve or extend this study by adopting the suggestions and eradicating the limitations of this study. Academicians could rely on the empirical results from this study to fill the scholarly gaps in the topics related to this study. Based on this study, the potential internal and external determinants from different aspects, namely MFIs specific determinants, macroeconomic conditions and social globalisation affect the financial and social efficiency of MFIs. Researchers could discover more potential factors that influence the efficiency of MFIs and conduct further research to verify the relationship and information to a greater extent. The results regarding the effects of social globalisation on the efficiency of MFIs could provide a new study area and different insights in the literature.
However, due to data limitation, the study could only include 88 MFIs from Thailand and Philippines over the study period from year 2010 to 2017 as the sample. Initially, the purpose of this study is to investigate the relationship between the efficiency of MFIs and MFI's specific determinants, macroeconomic factors and social globalisation measures over the Asia countries. As a consequence, the robustness and accuracy of the results may be affected to some extent. Another limitation is the data coverage period may be updated to a certain year, as the latest data are still being processed and has not been disclosed publicly. For instance, the KOF Globalisation Index provides the data up to year 2017, which means that the data for 2018 and 2019 is still in the processing step. Therefore, the coverage period for this study could only up until year 2017. Thus, the future researcher should take into consideration of these limitations and improve the study from time to time in order to produce a more reliable and updated research information.

\section{Acknowledgment}

We would like to thanks the editors and the anonymous referees of the journal for constructive comments and suggestions, which have significantly helped to improve the contents of the paper. Furthermore, special thanks to Geran Penyelidikan Sekolah Perniagaan dan Ekonomi (GPSPE) 6303804-10601 sponsored by Universiti Putra Malaysia as organisation that funded our research. The usual caveats apply.

\section{References}

Abayie, E., Amanor, K., \& Frimpong, J. (2011). The Measurement and Determinants of Economic Efficiency of Microfinance Institutions in Ghana: A Stochastic Frontier Approach. African Review of Economics and Finance, 2 (2), 149-166.

Abrar, A., \& Javaid, A. Y. (2016). The Impact of Capital Structure on the Profitability of Microfinance Institutions. South Asian Journal of Management Sciences, 10(1), 21-37. https://doi.org/10.21621/SAJMS.2016101.03

Accetturo, A., Barboni, G., Cascarano, M., Garcia-Appendini, E., \& Modena, F. (2019). The Anatomy of Cultural Proximity in Credit Markets.

Aghimien, P. A., Kamarudin, F., Hamid, M., \& Noordin, B. (2016). Efficiency of Gulf Cooperation Council Banks: Empirical evidence using data envelopment analysis. Review of International Business and Strategy, 26(1), $118-136$. https://doi.org/10.1108/RIBS-11-2013-0111

Ahmad, U. (2011). Efficiency analysis of micro-finance institutions in Pakistan. Munich Personal REPEC Archive (MPRA), Report No. 34215.

Al-Harbi, A. (2019). The determinants of conventional banks profitability in developing and underdeveloped OIC countries. Journal of Economics, Finance and Administrative Science, 24 (47), 4-28. https://doi.org/10.1108/JEFAS-05-20180043

Alhassan, A. (2015). Income diversification and bank efficiency in an emerging market. Managerial Finance, 41 (12), 1318-1335. https://doi.org/10.1108/MF-12-2014-0304

Ashenafi, D. S., \& Kingawa, C. D. (2018). Factors Affecting Profitability of Microfinance Institutions (A Study of MFIs in Southern Nation Nationalities Peoples Regional State). Journal of Economics and Sustainable Development, 9(5), 34-45

Autio, E. (2005). Creative tension: the significance of Ben Oviatt's and Patricia McDougall's article 'Toward a theory of international new ventures'. Journal of International Business Studies, 36 (1), 9-19. https://doi.org/10.1057/ palgrave.jibs. 8400117

Badenhorst-Weiss, J. A., Maurer, C., \& Brevis Landsberg, T. (2013). Developing measures for the evaluation of information flow efficiency in supply chains. Journal of Transport and Supply Chain Management, 7(1). https://doi.org/10.41 02/jtscm.v7i1.88 
Hafezali Iqbal Hussain, Fakarudin Kamarudin, Nazratul Aina Mohamad Anwar, Fadzlan Sufian, Azlan Ali, Mohd Haizam Saudi. Social Globalisation and Efficiency of Microfinance Institutions Nexus: Empirical Evidence on Financial and ...

Balli, F., Pericoli, F., \& Pierucci, E. (2018). Globalization and international risk-sharing: The role of social and political integration. European Journal of Political Economy 55: 324-345. https://doi.org/10.1016/j.ejpoleco.2017.12.006

Baneliene, R., \& Melnikas, B. 2020. "Economic Growth and Investment in R\&D: Contemporary Challenges for the European Union." Contemporary Economics 14 (1), 38-58. https://doi.org/10.5709/ce.1897-9254.331

Banker, R. D., \& Natarajan, R. (2005). Productivity change, technical progress, and relative efficiency change in the public accounting industry. Management Science, 51(2), 291-304. https://doi.org/10.1287/mnsc.1040.0324

Banker, R. D., \& Natarajan, R. (2008). Evaluating contextual variables affecting productivity using data envelopment analysis. Operations research, 56(1), 48-58. https://doi.org/10.1287/opre.1070.0460

Banker, R. D., Chang, H., \& Lee, S. Y. (2010). Differential impact of Korean banking system reforms on bank productivity. Journal of Banking \& Finance, 34(7), 1450-1460. https://doi.org/10.1016/j.jbankfin.2010.02.023

Banker, R. D., Charnes, A., \& Cooper, W. W. (1984). Some models for estimating technical and scale inefficiencies in data envelopment analysis. Management science, 30(9), 1078-1092. https://doi.org/10.1287/mnsc.30.9.1078

Bartova, L., \& Fandel, P. (2020). Membership in agricultural producer organizations and farm technical efficiency in Slovakia. Equilibrium. Quarterly Journal of Economics and Economic Policy, 15(3), 489-509. https://doi.org/10.241 36/eq.2020.022

Bassem, B. S. (2008). Efficiency of Microfinance Institutions in the Mediterranean: An Application of DEA. Transition Studies Review, 15(2), 343-354. https://doi.org/10.1007/s11300-008-0012-7

Berger, A. N., DeYoung, R., Genay, H., \& Udell, G. F. (2000). Globalization of financial institutions: evidence from cross border banking performance. Brookings-Wharton Papers on Financial Services 3, 23-158. https://doi.org/10.135 3/pfs.2000.0001

Bilan, Y., Vasilyeva, T., Kryklii, O., \& Shilimbetova, G. (2019). The creative industry as a factor in the development of the economy: dissemination of European experience in the countries with economies in transition. Creativity Studies, 12(1), 75-101. https://doi.org/10.3846/cs.2019.7453

Bogan, V., Johnson, W., \& Mhlanga, N. (2008). Does Capital Structure Affect the Financial Sustainability of Microfinance Institutions?

Boyd, J. H., \& De Nicolo, G. (2005). The theory of bank's risk-taking and competition revisited. Journal of Finance, 60(3), 1329-1343. https://doi.org/10.1111/j.1540-6261.2005.00763.x

Charnes, A., Cooper, W. W., \& Rhodes, E. (1978). Measuring the efficiency of decision-making units. European journal of operational research, 2(6), 429-444. https://doi.org/10.1016/0377-2217(78)90138-8

Chen, Y., Li, W., \& Jin, X. (2018). Volatility Spillovers between Crude Oil Prices and New Energy Stock Price in China. Romanian Journal of Economic Forecasting. 21(2), 43-62.

Chih, S. H., Liang, L. W., \& Huang, B. Y. (2018). The Study on the Relationship between Bank M\&A, SME Lending, Credit Guarantee and Bank Efficiency. Romanian Journal of Economic Forecasting. 21(2), 95-117.

Chu, S. F., \& Lim, G. H. (1998). Share performance and profit efficiency of banks in an oligopolistic market: evidence from Singapore. Journal of Multinational Financial Management, 8(2/3), 155-168. https://doi.org/10.1016/S1042444X(98)00025-5

Coad, A., Segarra, A., \& Teruel, M. (2011). Like milk or wine: Does firm performance improve with age? The Papers on Economics and Evolution. https://doi.org/10.2139/ssrn.1815028

Coakes, S. J., \& Steed, L. G. (2003). SPSS Analysis Without Anguish: Version 11.0 for Windows. 1st Edn., John Wiley and Sons Australia Limited, Milton, ISBN-10: 0470802774, pp: 242

Coelli, T. (1996). A guide to DEAP version 2.1: a data envelopment analysis (computer) program. Centre for Efficiency and Productivity Analysis, University of New England, Australia.

Cooper, W. W., Seiford, L. M., \& Tone, K. (2002). Data envelopment analysis. A Comprehensive Text with Models, Application, References and DEA-solver Software, Kluwer Academc Publishers.

De Bandt, O., \& Davis, E. P. (2000). Competition, contestability and market structure in European banking sectors on the eve of EMU. Journal of Banking \& Finance, 24(6), 1045-1066. https://doi.org/10.1016/S0378-4266(99)00117-X

Demirgunes, K., Ucler, G. (2015). Inter Relationship Between Profitability, Growth, And Size: Case of Turkey. Journal of Business, Economics \& Finance Issn: 2146-7943. https://doi.org/10.17261/Pressacademia.2015414534

Dreher, A. (2006). Does globalization affect growth? Evidence from a new index of globalization. Applied Economics, 38(10), 1091-1110. https://doi.org/10.1080/00036840500392078

Dreher, A., \& Gaston, N. (2008). Has Globalization Increased Inequality? Review of International Economics 16(3), 516536. https://doi.org/10.1111/j.1467-9396.2008.00743.x 
Dreher, A., Sturm, J. E., \& Ursprung, H. (2008). The impact of globalization on the composition of government expenditures: Evidence from panel data. Public Choice 134(3), 263-292. https://doi.org/10.1007/s11127-007-9223-4

Ebaid, E. I. (2009). The impact of capital-structure choice on firm performance: empirical evidence from Egypt. The Journal of Risk Finance, 10(5), 477-487. https://doi.org/10.1108/15265940911001385

Ezike, E. (2009). International Business Finance and Management. Lagos: Concept Publications Limited.

Ezzat, A. M., \& Fayed, M. E. 2020. "Central Bank Independence and Democracy: Does Transparency Matter?" Contemporary Economics 14(2), 90-112. https://doi.org/10.5709/ce.1897-9254.334

Fisman, R., Paravisini, D., \& Vig, V. (2017). Cultural proximity and loan outcomes. American Economic Review, 107 (2), 457-492. https://doi.org/10.1257/aer.20120942

Girardone, C., Molyneux, P., \& Gardener, E. P. M. (2004). Analysing the Determinants of Bank Efficiency: The Case of Italian Banks. Applied Economics, 36(3), 215-227. https://doi.org/10.1080/0003684042000175334

Grmanova, E., \& Pukala, R. (2018). Efficiency of insurance companies in the Czech Republic and Poland.Oeconomia Copernicana, 9(1), 71-85. https://doi.org/10.24136/oc.2018.004

Hao, L., Li, S. S., \& Marquis, C. (2017). Does Globalization Help Inclusive Growth? An Opportunity Structure Perspective. Retrieved from https://icsb.org/wp-content/uploads/2017/01/Liang_etal-USASBE2017.pdf

Haq, M., Skully, M., \& Pathan, S. (2010). Efficiency of Microfinance Institutions: A Data Envelopment Analysis. AsiaPacific Financial Markets, 17, 63-97. https://doi.org/10.1007/s10690-009-9103-7

Hermes, N., Lensink, R., \& Meesters, A. (2011). Outreach and Efficiency of Microfinance Institutions. World Development, 39(6), 938-948. https://doi.org/10.1016/j.worlddev.2009.10.018

Hintosova, A. B., Bobenic, T., Hajduova, Z., \& Szajt, M. (2020). "The influence of firm-specific factors on firms' performance." Polish Journal of Management Studies 21(2), 115-128. https://doi.org/10.17512/pjms.2020.21.2.09

Hossain, M. S., \& Khan, M. A. (2016). Financial Sustainability of Microfinance Institutions (MFIs) of Bangladesh. Developing Country Studies, 6(6), 60-78

Hussain, H. I., Hadi, A. R. A Mohamed-Isa, A., Salem, M. A., Kamarudin, F., \& Jabarullah, N. H. (2018). Adjustment to Target Debt Maturity and Equity Mispricing: Evidence from Asia Pacific. Polish Journal of Management Studies 17(2), 87-100. https://doi.org/10.17512/pjms.2018.17.2.08

Hussain, H. I., Kamarudin, F., Anwar, N. A. M., Nassir, A. M., Sufian, F., \& Mang, T. K. (2020a). Impact of Country's Governance Dimensions on Bank Revenue Efficiency: Overview on Middle East, Southeast Asia, and South Asia Countries. Transformations in Business \& Economics, 19(1), 49, 191-228.

Hussain, H., I., Kot, S., Kamarudin, F., \& Mun, W. C. (2020b). "The Nexus of Competition Freedom and the Efficiency of Microfinance Institutions." Journal of Competitiveness 12(2), 67-89. https://doi.org/10.7441/joc.2020.02.05

Hussain, H. I., Szczepanska-Woszczyna, K., Kamarudin, F., Anwar, N. A. M., \& Saudi, M. H. M. (2021). Unboxing the black box on the dimensions of social globalisation and the efficiency of microfinance institutions in Asia. Oeconomia Copernicana, 12(3), 557-592. https://doi.org/10.24136/oc.2021.019

Kamarudin, F., Anwar, N. A. M., Abdul Rahim, N., \& Mohd Said, R. (2019). Total Factor Productivity Change of Banks and Country Governance's Dimensions Nexus: Empirical Evidence from Islamic and Conventional Banks. 2nd International Research Conference on Humanities, Social Sciences and Technology.

Kamarudin, F., Nassir, A. M., Yahya, M. H., Said, R. M., \& Nordin, B. A. A. (2014). Islamic banking sectors in Gulf Cooperative Council countries: Analysis on revenue, cost and profit efficiency concepts. Journal of Economic Cooperation and Development, 35(2), 1-42.

Kamarudin, F., Nordin, B. A. A., \& Nassir, A. M. (2013). Price Efficiency and Returns to Scale of Banking Sector in Gulf Cooperative Council Countries: Empirical Evidence from Islamic and Conventional Banks. Economic Computation and Economic Cybernetics Studies and Research, 47(3), 215-236.

Kamarudin, F., Sufian, F., \& Nassir, A. M. (2016). Global financial crisis, ownership and bank profit efficiency in the Bangladesh's state owned and private commercial banks. Contaduría y Administración, 61(4), 705-745. https://doi.org/10.1016/j.cya.2016.07.006

Kamarudin, F., Zack, H. C., Sufian, F., \& Anwar, N. A. M. (2017). Does productivity of Islamic banks endure progress or regress? Empirical evidence using Data Envelopment Analysis based Malmquist Productivity Index. Humanomics, 33(1), 84-118. https://doi.org/10.1108/H-08-2016-0059

Kuder, D. (2015). Impact of institutional factors on economic growth in the United States in the years $1979 ? 2007$. Oeconomia Copernicana, 6(1), 137-159. https://doi.org/10.12775/OeC.2015.008

Kipesha, E. (2013). Production and Intermediation Efficiency of Microfinance Institutions in Tanzania. Research Journal of Finance and Accounting, 4(1), 149-160. 
Hafezali Iqbal Hussain, Fakarudin Kamarudin, Nazratul Aina Mohamad Anwar, Fadzlan Sufian, Azlan Ali, Mohd Haizam Saudi. Social Globalisation and Efficiency of Microfinance Institutions Nexus: Empirical Evidence on Financial and ...

Kyereboah-Coleman, A. (2007). The impact of capital structure on the performance of microfinance institutions. Journal of Risk Finance (Emerald GroupPublishing Limited), 8(1), 56-71. https://doi.org/10.1108/15265940710721082

Lee, C. C., Lee, C. C., \& Lien, D. (2020). Income inequality, globalization, and country risk: a cross-country analysis. Technological and Economic Development of Economy, 26(2), 379-404. https://doi.org/10.3846/tede.2019.11414

Lebovics, M., Hermes, N., \& Hudon, M. (2016). Are Financial and Social Efficiency Mutually Exclusive? A Case Study of Vietnamese Microfinance Institutions. Annals of Public and Cooperative Economics, 87(1), 55-77. https://doi.org/10.1111/apce.12085

Ledgerwood, J. (1998). Microfinance handbook: An Institutional and Financial Perspective. https://doi.org/10.1596/978-08213-4306-7

MacGregor, R. K., Sroka, W., \& MacGregor Pelikanova, R. (2020). "A comparative study of low-level management's attitude to marketing and innovations in the luxury fashion industry: pro-or anti-CSR?" Polish Journal of Management Studies 21 (2), 240-255. https://doi.org/10.17512/pjms.2020.21.2.17

McDonald, J. (2009). Using least squares and tobit in second stage DEA efficiency analyses. European journal of operational research, 197(2), 792-798. https://doi.org/10.1016/j.ejor.2008.07.039

Marks-Bielska, R., Lizinska, W., Wojarska, M., \& Babuchowska, K. (2020). Institutional efficiency versus stability of local governments in basic areas of activity: the case of Poland. Equilibrium. Quarterly Journal of Economics and Economic Policy, 15(3), 463-487. https://doi.org/10.24136/eq.2020.021

Melnikas, B. (2019). Sustainable social development, economic growth and technological breakthroughs: creativity and creative change. Creativity Studies, 12 (2), 301-314. https://doi.org/10.3846/cs.2019.10335

Mia, M. A., \& Ben Soltane, B. I. (2016). Productivity and its determinants in microfinance institutions (MFIs): Evidence from South Asian countries. Economic Analysis and Policy, 51, 32-45. https://doi.org/10.1016/j.eap.2016.05.003

Muda, M., Shaharuddin, A., \& Embaya, A. (2013). Comparative analysis of profitability determinants of domestic and foreign Islamic banks in Malaysia. International Journal of Economics and Financial Issues, 3(3), 559

Mushtaq, A., Chen, Z., Din, N. U., Ahmad, B., \& Zhang, X. (2020). Income inequality, innovation and carbon emission: Perspectives on sustainable growth. Economic Research-Ekonomska Istrazivanja, 33(1), $769-787$. https://doi.org/10.1080/1331677X.2020.1734855

Nguyen, H. T. K. \& Nguyen, D. T. (2018). Globalisation and Bank Performance in Vietnam. Malaysian Journal of Economic Studies, 55(1), 49-70. https://doi.org/10.22452/MJES.vol55no1.3

Nieto, B., Serrano-Cinca, C., \& Mar Molinero, C. (2009). Social Efficiency in Microfinance Institutions. Journal of the Operational Research Society, 60, 104-119. https://doi.org/10.1057/palgrave.jors.2602527

Norris, P. (2000). Global governance and cosmopolitan citizens, in J. S. Nye, \& J. D. Donahue (Eds), Governance in a Globalizing World 155-77. Washington, DC: Brookings Institution Press.

Opperud, J., \& Torp, K. M. (2016). The efficiency of Microfinance Institutions compared to Norwegian Savings Banks.

Pasiouras, F., \& Kosmidou, K. (2007). Factors influencing the profitability of domestic and foreign banks in the European Union. Res. Int. Bus. Financ. 21(2), 222-237. https://doi.org/10.1016/j.ribaf.2006.03.007

Pradhan, R. S., \& Khadka, N. (2017). The Effect of Debt Financing on Profitability of Nepalese Commercial Banks. SSRN Electronic Journal. https://doi.org/10.2139/ssrn.3044107

Sanchez, R. (1997). Financial Efficiency and Economic Growth: The Case of Spain. International Advances in Economic Research, 3, 333-351. https://doi.org/10.1007/BF02295212

Sealey Jr, C. W., \& Lindley, J. T. (1977). Inputs, outputs, and a theory of production and cost at depository financial institutions. The journal of finance, 32(4), 1251-1266. https://doi.org/10.1111/j.1540-6261.1977.tb03324.x

Sell, F. L. (2020). "Static and Dynamic Price Effects Motivated by Innovation and Imitation: Novel Insights Using the Barone's Curve." Contemporary Economics 14 (1), 73-90. https://doi.org/10.5709/ce.1897-9254.333

Shafai, N. A., Nassir, A. M., Kamarudin, F., Rahim, N. A., \& Ahmad, N. H. (2019). Dynamic Panel Model of Dividend Policies: Malaysian Perspective. Contemporary Economics, 13(3), 239-252. https://doi.org/10.6007/IJARAFMS/v10i3/7845

Silva, A. C., \& Chavez, G. A. (2015). Microfinance, country governance, and the global financial crisis. Venture Capital, 17(1/2), 191-213. https://doi.org/10.1080/13691066.2015.1021032

Skare, M. \& Prziklas Druzeta, R. (2016). Poverty and Economic Growth: A Review. Technological and Economic Development of Economy, 22(1), 156-175. https://doi.org/10.3846/20294913.2015.1125965

Staikouras, C., Mamatzakis, E., \& Koutsomanoli-Filippaki, A. (2008). An empirical investigation of operating performance in the new European banking landscape. Global Finance Journal, 19(1), 32-45. https://doi.org/10.101 6/j.gfj.2008.01.001 
Stiroh, K. J., \& Rumble, A. (2006). The dark side of diversification: The case of US financial holding companies. J. Bank. Financ, 30(8), 2131-2161. https://doi.org/10.1016/j.jbankfin.2005.04.030

Sufian, F. (2004). The efficiency effects of bank mergers and acquisitions in a developing economy: Evidence from Malaysia. International Journal of Applied Econometrics and Quantitative Studies, 1(4), 53-74.

Sufian, F., \& Habibullah, M. S. (2010). Developments in the efficiency of the Thailand banking sector: a DEA approach. https://doi.org/10.1504/IJAMS.2010.036593

Sufian, F., \& Habibullah, M. S. (2012a). Globalization and bank efficiency nexus: Symbiosis or parasites? Review of Development Finance, 2, 139-155. https://doi.org/10.1016/j.rdf.2012.09.003

Sufian, F., \& Habibullah, M. S. (2012b). Globalizations and bank performance in China. Research in International Business and Finance, 2 (2), 221-239. https://doi.org/10.1016/j.ribaf.2011.12.005

Sufian, F., \& Habibullah, M. S. (2014). The impact of forced mergers and acquisitions on banks' total factor productivity: empirical evidence from Malaysia. Journal of the Asian Pacific Economy, 19(1), 151-185. https://doi.org/10.10 80/13547860.2013.818428

Sufian, F., \& Kamarudin, F. (2014a). Efficiency and Returns to Scale in the Bangladesh Banking Sector: Empirical Evidence from the Slack-Based DEA Method. Inzinerine Ekonomika - Engineering Economics, 25(5), $549-557$. https://doi.org/10.5755/j01.ee.25.5.5035

Sufian, F., \& Kamarudin, F. (2014b). "The impact of ownership structure on bank productivity and efficiency: Evidence from semi-parametric Malmquist Productivity Index." Cogent Economics \& Finance 2(1), 1-27. https://doi.org/10.10 $80 / 23322039.2014 .932700$

Sufian, F., \& Kamarudin, F. (2015). Determinants of revenue efficiency of Islamic banks: Empirical evidence from the Southeast Asian countries. International Journal of Islamic and Middle Eastern Finance and Management, 8(1), 3663. https://doi.org/10.1108/IMEFM-12-2012-0114

Sufian, F., \& Kamarudin, F. (2016). The impact of globalization on the performance of Banks in South Africa. Review of International Business and Strategy, 26 (4), 517-542. https://doi.org/10.1108/RIBS-02-2016-0003

Sufian, F., Kamarudin, F., \& Md. Nassir, A. (2017). Globalization and bank efficiency nexus: empirical evidence from the Malaysian banking sector. Benchmarking: An International Journal, 24 (5), 1269-1290. https://doi.org/10.1108/BIJ09-2014-0090

Tan, A. Y., \& Floros, C. (2012). Bank profitability and inflation: the case of China. Journal of Economic Studies, 39 (6). https://doi.org/10.1108/01443581211274610

Teto, E, Dallocchio, M., \& Aniasi, A. (2019). The relationship between twitter and stock prices. Evidence from the US technology industry. Technological Forecasting and Social Change. 149, 119747. https://doi.org/10.1016/j.techfore. 2019.119747

Thoraneenitiyan, N., \& Avkiran, N.K. (2009). Measuring the Impact of Restructuring and Country Specific Factors on the Efficiency of Post-Crisis East Asian Banking Systems: Integrating DEA with SFA. Socio-Economic Planning Sciences, 43 (4), 240-252. https://doi.org/10.1016/j.seps.2008.12.002

Von Stauffenberg, D., Tor, J., Naomi, K., \& Maria, C. (2003). Performance Indicators for Microfinance Institutions. A Technical Guide.

White, H. (1980). A heteroskedasticity-consistent covariance matrix estimator and a direct test for heteroskedasticity. econometrica, 48(4), 817-838. https://doi.org/10.2307/1912934

Wijesiri, M., \& Meoli, M. (2015). Productivity change of microfinance institutions in Kenya: A bootstrap Malmquist approach. Journal of Retailing and Consumer Services, 25, 115-121. https://doi.org/10.1016/j.jretconser.2015.04.004

Wijesiri, M., Vigano, L., \& Meoli, M. (2015). Efficiency of microfinance institutions in Sri Lanka: a two-stage double bootstrap DEA approach. Economic Modelling, 47, 74-83. https://doi.org/10.1016/j.econmod.2015.02.016

Yazdanfar, D. (2013). Profitability determinants among micro firms: evidence from Swedish data. International Journal of Managerial Finance, 9(2), 151-160. https://doi.org/10.1108/17439131311307565

Yazdi. S. K., \& Dariani, A. G. (2019). CO2 emissions, urbanisation and economic growth: evidence from Asian countries. Economic Research-Ekonomska Istrazivanja, 32(1), 510-530. https://doi.org/10.1080/1331677X.2018.1556107

Zeller, M., \& Meyer, R. L. (2002). Improving the performance of microfinance: financial sustainability, outreach, and impact. In: Zeller, M., Meyer, R. L. (Eds.), The Triangle of Microfinance. The Johns Hopkins university press, 1-15 
Hafezali Iqbal Hussain, Fakarudin Kamarudin, Nazratul Aina Mohamad Anwar, Fadzlan Sufian, Azlan Ali, Mohd Haizam Saudi. Social Globalisation and Efficiency of Microfinance Institutions Nexus: Empirical Evidence on Financial and ...

\section{Authors' Biographies}

Hafezali Iqbal Hussain, PhD, is an Associate Professor at Taylor's Business School in Malaysia and Visiting Professor at University of Economics and Human Sciences Okopowa Warsaw, Poland. He received his PhD in Finance at the University of Hull in the UK; was formerly a chartered accountant at Citigroup; his work has appeared in several peerreviewed finance, management, education, and scientific journals; he has presented at various conferences.

Fakarudin Kamarudin, $\mathrm{PhD}$ (corresponding author), is a Senior Lecturer at the School of Business and Economics, Universiti Putra Malaysia (UPM). He obtained his Ph.D majoring in Finance from UPM in 2015. He has a Master of Science (MSc) in Finance in 2010 from the same university. He currently conducts lectures on Financial Management, Econometrics and Statistic.

Nazratul Aina Mohamad Anwar, PhD, is the Senior Lecturer at the Faculty of Economics and Muamalat at the Universiti Sains Islam Malaysia (USIM). She obtained her PhD majoring in Accounting at UPM in 2016.

Fadzlan Sufian, PhD, is a Professor at Universiti Teknologi MARA, Melaka, Alor Gajah Campus. He holds a PhD in Economics (Financial Economics) at Universiti Putra Malaysia. His articles have appeared in more than 100 local and international journals. His research concerns the measurement of the performance of banking and financial sectors.

Azlan Ali, PhD, is Associate Professor at University College of Technology Sarawak. Dr. Azlan Ali was appointed as Deputy Vice-Chancellor (Academic). Prior to this, he was with AmBank Berhad and was attached to Department of Corporate Banking. Dr. Azlan Ali was also chosen to be a researcher in Varna University of Economics, Bulgaria.

Mohd Haizam Saudi, PhD, experienced Professor graduated from Ohio University, USA and Southern Cross University, Australia. Deputy Vice Chancellor of Student Affairs \& Alumni in Kolej Universiti Poly-Tech MARA, Malaysia and currently hold the position of Vice Rector of Research, Development and Cooperation at Widyatama University, Indonesia.

The article has been reviewed. Received in May 2021; accepted in February 2022.

This article is an Open Access article distributed under the terms and conditions of the Creative Commons Attribution 4.0 (CC BY 4.0) License (http://creativecommons.org/licenses/by/4.0/) 